\title{
原子カと国際問題
}

\section{International Issues on Nuclear Power}

\author{
（1993年 12月21日 受 理）
}

\begin{abstract}
本「特集」では, 原子力に関連した国際問題を取り上げてみた。原子力に関するニュースは, 新聞 やテレビから毎日のように我々の耳に飛び込んでくるが, エッセンスを要領よくまとめたものは 案外少ないかもしれない。本稿では，国内外で直接，間接に原子力に携わっておらられる方々に，最 新の情報を交えつつ様々な立場, 観点から国際問題をご紹介いただければと思っている。誌面の都 合上，重要な問題すべてを網羅することはできないこと，また，発行の時点ではすでに古くなっ た情報があるかもしれない点についてはご容教願いたい。（担当編集委員·稲葉次郎, 斎藤公明）
\end{abstract}

I.はじめに

II 、エネルギー・噮境と原子力を取り巻く世界

III. CIS, 東欧に関する諸問題
IV. 原子力技術と国際協力

V. 核不拡散·核軍称と原子力平和利用 VI. まとめ

\section{I .はじめに}

\section{国際原子力機関(IAEA) 町 末男}

1990年に53億であった世界人口は，2025年には 90億になると予測されている。この爆発的な人口 増加はエネルギー需要の急激な拡大につながる。 化石燃料のむたらす酸性雨の被害はすでに顕在化 しているが, 加えて地球温暖化が人類の未来に及 ぼす影響が懸念されている。

このような状況をみれば, 現在世界で424基の 発電所が動いており (IAEA 調查), 17\%の電力を 賄っている原子力発電の重要性は将来ますます高 まっていくであろう。事実, 1993年 6 月 4 日IEA (国際エネルギー機関)の閣僚理事会は，原子力エネ ルギーを「エネルギー供給に貢献, 温暖化対策とし て重要」と前向きに位置づけている。

しかし, 日本, 韓国, 中国などの一部のアジア諸 国を除けば，原子力発電は明らかに停滞状態にあ る。ヨーロッパでは, 原子力発電所の発注が長く 途絶えているが, 長期エネルギー政策の議論は不 十分である。

注目される米国クリントン政権下で，新たなエ ネルギー政策について，ワシントンから林参事官 が興味深い報告を寄稿している。天然がス利用が
浮上し，原子力の停滞は続きそうである。欧米の 停滞状況を改善するためには, エネルギー戦略の 中で，国際的な規模での原子力への理解之認識が

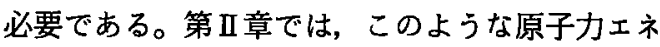
ルギーの国際動向が紹介される。

ロシアを含む東欧諸国への支援は緊急な課題に なっている。これらの国は, 安全確保のために改 造を要するソ連型原子力発電所に電力の多くを依 存しているので, 安全改善の速やかな実施を必要 としている。この問題に対する G-24, IAEAなど の協力計画は大きな関心事である。この点をブ

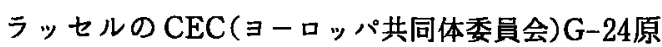
子力安全支援調整センターで直接この仕事に当 たっている下村氏に紹介して頂く。さらに，具体 的な安全上の課題と改善の状況について, IAEA のWWERに関する支援プロジェクトの運営委員 である鴻坂氏が報告している。

一方, ソ連崩壊と冷戦の終了に伴う核兵器解体 からの余剩核物質の処理, 核兵器技術に関する頭 脳流出問題も暞案事項である。これらに加えて チェルノブイル事故のその後など, 東欧・旧ソ連 に関する諸問題が第吕章で論じられる。

第IV章では，原子力平和利用の推進において重 要な国際協力の役割が紹介される。その代表例が 国際熱核融合実験炉(ITER)計画であり，日本は 4 
極の重要なメンバーとして期待されている。1992 年 6 月にワシントンで工学設計活動(EDA)協定が 調印され，すでに実施されつつある具体的な活動 が ITER Council の吉川共同議長(原研)から紹介 される。

高速炉「むんじゅ」の運転開始が近い。FBR 之 $\mathrm{Pu}$ 利用には様々な国際的な議論があり，期待も 大きい。鈴木教授がこれらの点について論じてい る。

一方, 開発途上国は工業の近代化,生活の向上 に結び付く原子力技術の利用に熱心で，IAEA む 支援に力を入れている。日本はIAEAのむとでの
$\mathrm{RCA}$ (アジア地域原子力協力協定)協力で大きな国際 貢献を果たしてきているし，最近では 2 国間協力 あ積極的に進めている。

冷戦終了後，核不拡散のあり方あ新たな問題に 直面している。北朝鮮の NPT (核不拡散条約)脱退 声明への対応, 核兵器解体などからの余剩Puの管 理などもその一つである。P5国と日·独はIAEA の場で国際 Pu管理構想の検討を始めている。核 拡散防止で最も重要なのは政治的緊張の緩和であ ることはいうまであない。これらの問題について 第 V章に, 元IAEA 理事会議長の遠藤大使に執筆 頂いている。

\section{II、エネルギー・環境と原子力を 取り巻く世界}

\section{П-1.世界のエネルギー事情と} 原子力開発

科学技術庁原子力局 石田 寛人

\section{1. 世界のエネルギー事情と原子力}

\section{（1）世界のエネルギー需要の推移}

世界のエネルギー需要は, 1970年代の 2 度の才 イルショックを経て, 各国においてェネルギー多 消費型加ら寡消費産業への構造転換や省エネル ギ一努力が進められ，1 次的に和基調で推移し た。しかし，1983年以降，エネルギー価格の低水 準での推移,好調な景気を背景に，エネルギー需 要は再び増加傾向に転じた。

一方，IEA (国際ェネルギー機関)の予測による と, 今後のエネルギー需要は平均年率 $2.0 \%$ で増 加し，2010年には1990年に対し約48\%増加すると されている。地域別には開発途上国で需要の伸び が顕著となり，先進国については，経済成長の鈍 化,省エネルギー対策の推進等を受け，エネル ギー需要の伸びが開発途上国に比して鈍ることが 予測されている。

（2）世界のエネルギー供給構造の推移 この間, エネルギーの供給構造は第 1 次オイル
ショックまでの石油への大幅な依存構造から，原 子力, 天然ガス等の石油代替エネルギーへの依存 度を高めてきた。

IEAの予測によると，今後とも石油代替エネル ギーの導入が進むとされている。また，近年大き くクローズアップされている地球温暖化や酸性雨 等の地球環境問題の観点から，原子力をはじめと した非化石エネルギーへの依存度が今後とあ大き くなると予測されている。

\section{(3) 世界の原子力発電の現状}

世界における原子力発電所は1993年 6 月末現在 で, 416 基が運転中であり,設備容量は 3 億 4,390 万 $\mathrm{kW}$ である。一方, 原子力の総発電電力量につい ては，1992年実績で 2 兆276億 $\mathrm{kWh}$ に達し，世 界の総発電電力量の約 $1 / 6$ を占めた。これは約 4 億 2,600 万 $\mathrm{t}$ の石油に相当し，中東諸国全体の年 間石油生産量(1992年実縝約 8 億9, 970万 t)のほぼ半 分近くに相当する。

世界各国については，1993年 6 月現在で，米国 が108基の発電用原子炉を運転中であり，世界第 1 の原子力発電設備を有している。また，フラン スは55基の発電用原子炉を有し，国内の約73\%を 原子力発電で賄っている。

原子力発電は1951年, 米国において初めて発電 が行われて以来順調に增え続けてきたが，1986年 のチェルノブイル原子力発電所事故後, 一部の国 においては原子力政策の見直しや新規原子力発電 所の建設中止等, 原子力開発利用が停滞してい 
る。しかし，原子力発電はエネルギー源の多様化 に貢献するとともに，地球温暖化防止のための有 効な手段のひとつとして，その役割および必要性 が再認識され，一部の国・地域ではエネルギー政 策の見直しゃ，原子力発電所建設計画が再開され る等の動きがでている。

一方，旧ソ連・中東欧諸国の原子力発電所の安 全性確保は，世界的に重大な踒念材料であるとし て，国際的に支援方策が検討されている。1993年 7 月の東京サミットではミュンヘン・サミットの 行動計画の実施状況が評価された。経済宣言にお いて，短期的措置については 2 国間支援，原子力 発電所安全支援基金の設置等で進展があることを 評価するとともに，今後の課題として支援を遅滞 なく実行に移し，安全性向上を図ることが重要て あるとしている。また，長期的措置については， 世界銀行および IEA の報告を参考にしつつ今後 の支援の枠組みを策定することとし，各当事国が 危険な原子力発電所の早期閉鎖を可能にするよう なエネルギー計画を支援し，世界銀行等がそのた めの融資政策の調整を図れるようにすることを目 標としている。

\section{2. 我が国のエネルギー事情}

1992年度の我が国のエネルギー需要は, 調整過 程に入った影気を背景に伸びが鈍化し，対前年度 比0.5\%增に止まったが，1987〜1991年度は，内 需主導型の景気拡大を背景に $3 \sim 5 \%$ 程度の高い 伸びで推移してきている。

また，エネルギー利用部門別に見ると，民生， 運輸の両部門が産業部門を上回り、今後のエネル ギー需要は堅調に增加することが予想される。

一方，我が国のエネルギー供給構造を見ると， 1 次エネルギー総供給の $80 \%$ 以上を海外に依存し ており，またほぼ全量を輸入に頼っている石油へ の依存度は60\%近くになっている。また，湾岸危 機において改めて認識されたように，我が国は輸 入原油の約70\%を中東地域に依存しており，その エネルギー供給構造は他の先進諸国に比べて極め て脆弱である。エネルギーの安定供給確保に加 え, 地球環境問題に関して, 持続的な経済発展を 確保しつつ, 人間活動と環境保全の両立を図るた
め, エネルギー政策においても最大限の対応が必 要である。このような考えに基づき，政府は 1990 年10月「石油代替エネルギーの供給目標」を決定 し, 石油依存度の低減, 原子力や新・再生可能エネ ルギーの導入を図る等の総合的エネルギー政策を 推進している。

\section{3. 我か国の原子力開発利用の現状}

\section{（1）原子力発電の現状}

我が国が主要な石油代替エネルギーのひとつと して推進する原子力については，燃料であるウう ンが比較的世界に広く分布しており，政治的にも 経済的にも安定した地域が多いため，燃料の供給 安定性が高い。また，国内における核然料サイク ルの確立により，ウランの利用効率を飛躍的に高 め，準国産エネルギーとあ位置づけることが可能 であるなど供給安定性に優れている。さらに, 1989年ベースでの耐用年を通じた発電原価を見る と, 原子力は石油, 石炭, 天然ガスに比べて, 経済 的に優れている。環境面においても，二酸化炭 素, 窒素酸化物等を排出せず，地球温暖化をはじ めとした地球環境問題の解決に当たって重要な役 割を果たすことが期待されている。

したがって，我が国において，エネルギーのべ ストミックスを図る上で，また世界的なエネル ギーの安定供給の確保を図り，地球環境問題の解 決に貢献するなど国際的な責務を果たす上で，供 給安定性, 経済性,環境影響の面で優れた原子力を 主要なエネルギー源と位置づけ，その開発利用を 進めていくことが重要である。

具体的には, 1993年 9 月現在で，運転中のもの が研究開発段階のものを含め 46 基，3，736.1万 $\mathrm{kW}$ あり，1992年度には総発電電力量(電気事業 用)の $28.2 \%$ 賄っていた原子力発電を，2010年 度には $43 \%$ に増加させることを目標としている。

\section{（2）核燃料サイクルの現状}

ウラン資源を有効に活用し，原子力発電の供給 安定性を高めるためには核燃料サイクルを確立す ることが不可欠であり，我が国では動然事業団お よび原研が中心となって研究開発を進めている。 このうち, 核燃料の再転換・成形加工については, すでに民間において事業化が進められており，多 


\section{くの実績が積まれている。}

我が国の原子力開発利用は，使用済み燃料を再 処理し，回収されたプルトニウムおよびゥランを リサイクルし，核然料として再処理することを目 指す，再処理一リサイクル路線を一貫している。 原子力はもともと少量の資源から，技術によって 大量のエネルギーを生み，消費する資源量および 発生する廃棄物量が少ないという特長を有してい るが，核燃料リサイクルの実現により，その供給 安定性, 資源の節約之再利用が一層高められる。 そのため本政策は，我が国のような資源大量消費 国が率先して取り組むべきりサイクル社会形成に 貢献するものとして重要な位置づけにある。

（3）今後の原子力開発利用の進展に向けて

これまで見てきたように，我が国の原子力開発 利用は着赛に推進してきているが, 東西冷戦の終 了,核兵器の拡散に対する眯念の高まり,地球環境 問題に対する意識の向上等の世界状況の変化に伴 い, 今後の展開について検討すべき時期にきてい る。

我が国においては，38年間続いた自民党政権か
ら 8 党派による連立政権が，1993年 8 月に樹立さ れた。その樹立に際し，エネルギー政策などの基 本重要政策については，原則として今までの国の 政策を継承することが連立与党間で合意されてい る。原子力開発利用についても，現在我が国の絵 発電電力量(電気事業用)の30\%近くを担うに至っ ており，エネルギーの安定的確保を図る上で不可 欠であり，今後とも国民の理解と協力を得なが ら, 安全の確保を大前提に着実にその開発利用を 進めていくこととしている。

このような環境変化の中で，21世紀を見据えて 我が国のとるべき原子力開発の基本方針を明らか にするため, 現在, 原子力委員会において「原子 力開発利用長期計画」の見直しが行われている。

激動する国際情勢の中で, 原子力開発利用を推 進し，我が国および世界のエネルギーの安定供給 の確保等を図るとともに, 原子力の平和利用の世 界的率引国として国際的に積極的な貢献を行うた め, 今回の長期計画の見直しは極めて重要なもの であり, 本計画策定に向け, 最大限の努力が求め られている。

\section{II-2.エネルギー資源と環境コスト}

電力中央研究所 内山洋司

\section{1. 世界のエネルギー需給動向}

世界のエネルギー消費は，1970年代の石油危機 で一時的に減少したものの, 1980年半ばに石油価 格の暴落むおって, それ以降, 再び増加し始めて いる。現在のエネルギー消費の内訳を見ると，最 も多いのが石油で全体の40\%にあなる。次いで, 石炭30\%, 天然ガス $20 \%$ と続いており，化石然料 だけで全体の $90 \%$ 近くにあなる。原子力は, 発電 量では全体の $17 \%$ のェアであるが, エネルギー 消費では，まだわずか $5 \%$ に過ぎない。

第 П-1 図は，世界のエネルギー消費について， 過去の実績と将来の動向を供給源別に描いたもの である。それによると，世界のエネルギー消費 は，1950年からわずか 40 年間で 4.5 倍にまで増大
している。図に示す将来のエネルギー需要は，世 界の 1 人当りのエネルギー消費を今後は増やさな いという仮定のもとに, 1990年のエネルギー消費 1.52 石油 $\mathrm{t} /$ 人・年を用いて，人口に比例して計算 したものである。

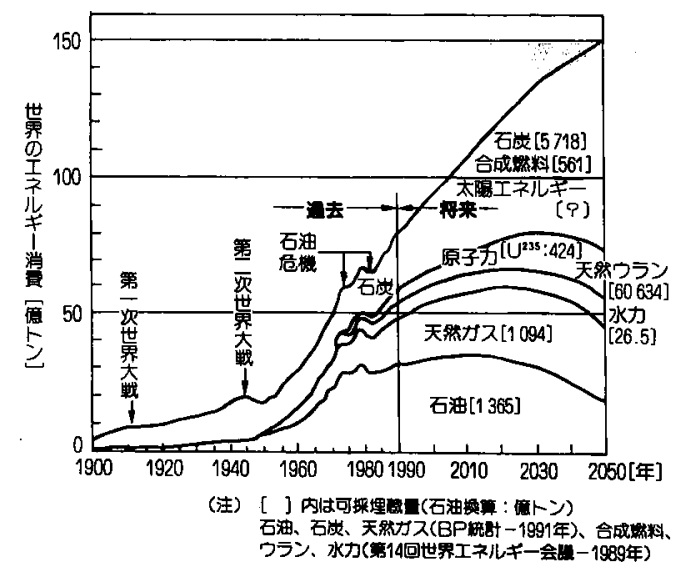

第 II-1 図 世界のエネルギー需給動向 ${ }^{(1)}$ 
このエネルギー需要を賄うのに要するエネル ギー資源量について調べてみよう。石油の残存可 採埋蔵量は，末発見量も含めて 1 兆 5,000 億バ一 レル程度あるといわれているが, 今の生産量で消 費し続けると2010年前後には減産し始めることに なる(2)。天然ガスも今の可採埋蔵量から推定する と2030年頃をピークに減産していくことになる。

結局, 不足分を補うエネルギー源は, 石炭と合成 燃料か原子力, あるいは再生可能エネルギーにな る。水力は再生可能エネルギーの中で最も経済性 に優れ, 今後も開発に向けて一層の努力を期待し たい。しかし, 今日の大量エネルギー消費社会を 支えるには限界がある。四に示す水力の開発規模 は、これまでの開発の増加率に合わせて想定した あのである。原子力についてむ, 水力と同じょう に過去の開発増加率と同じ割合で開発できたとす ると，将来の供給規模は図の通りである。残され た大半のエネルギー需要は, 石炭と合成燃料(重 質油, オイルシェール,タールサンド)あるいは太陽光 などの自然エネルギーで賄わなければならない。

あし，それが石炭や合成燃料で賄ったとする 之, 世界の $\mathrm{CO}_{2}$ 排出量む急增し, 2020 年には現在 よりも1.5倍に，そして2050年には2.1倍にまで達 する。環境学者の多くは，地球温暖化を防ぐに は, 将来の $\mathrm{CO}_{2}$ 排出レべルを現状か, それ以下に 抑えるべきであると警告している。しかし，その 目標は, このまま世界の人口が増え, かつ増大し たエネルギー需要を化石燃料に依存するのであれ ば, 不可能であることは明らかである。

\section{2. 発電プラントの $\mathrm{CO}_{2}$ 排出量}

「原子力発電は, プラントの建設やU濃縮など に大量のエネルギーを消費するから，それによっ て間接的に発生する $\mathrm{CO}_{2}$ は意外に多いのではない か?」という質問がしばしば聞かれる。この疑問 に答えるためには，発電プラントの燃料の採掘か ら搬入, 発電, 廃秦物処理処分に至るすべてのプロ セスについて投入エネルギーを調べ，それらの種 類と量から $\mathrm{CO}_{2}$ 排出量を求める必要がある。

発電プラントの $\mathrm{CO}_{2}$ 排出量は, ライフサイクル において各プロセスの建設と運用に消費する資材 およびェネルギーの種類と量を明らかにすれば,
それにそれぞれの $\mathrm{CO}_{2}$ 原単位を卦けることで計算 できる。

第 II-2 図は, 発電プラントの $\mathrm{CO}_{2}$ 排出量を トータルシステムから分析した結果である。図の $\mathrm{CO}_{2}$ 原単位は, プラントの寿命30年間にすべての プロセスから発生する $\mathrm{CO}_{2}$ 量を, その間に発電し た発電量で割った値である。 $\mathrm{CO}_{2}$ 排出量には, 各 プロセスの設備之運用からの発生量のほかに, 燃 料採掘時のメタン漏れ, 粗天然ガス中の $\mathrm{CO}_{2}$, 発電 時の燃料燃焼，セメント製造時の $\mathrm{CO}_{2}$ が含まれて いる。

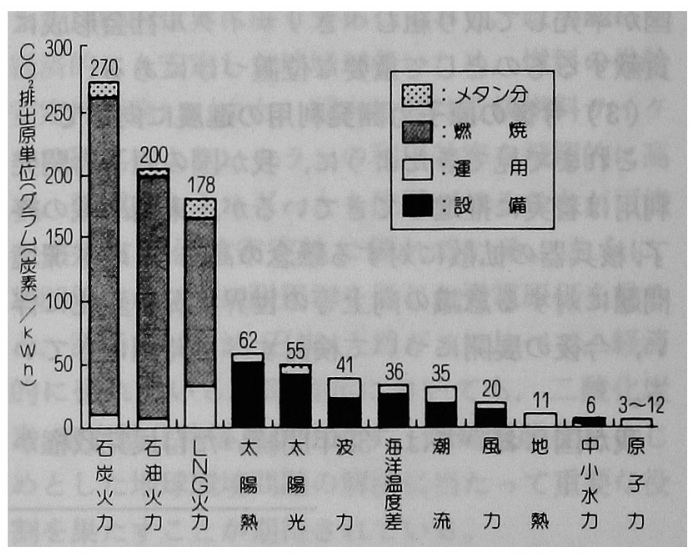

第 II-2図 各種発電プラントの温暖化影響 の比較

図から, 原子力, 中小水力, 地熱, その他の自然 エネルギー，そして火力発電の順に $\mathrm{CO}_{2}$ 排出量が 大きくなっていることがわかる。特に火力発電の $\mathrm{CO}_{2}$ 排出量は, 原子力ゃ自然エネルギーに比べて かなり大きい。これは，発電時の燃料から直接に 排出する $\mathrm{CO}_{2}$ 量が, 設備や運用, あるいはメタン 漏れといった間接的な $\mathrm{CO}_{2}$ 量に比べ圧倒的に多い ためである。

原子力発電は, 燃料から $\mathrm{CO}_{2}$ を排出しない分, $\mathrm{CO}_{2}$ 排出量は少なく，その值は $\mathrm{LNG}$ 火力の $1 / 15$ 〜1/60である。原子力発電は核燃料サイクルのプ ロセスが複雑で, そういったプラントの建設には 大量の資材とエネルギーを投入している。しか し，それらを発電所 1 基分に換算し，加耐用年 間で平均化すると, 結果的には設備加らの発生量 は大したことはなく，運用からの値の方が圧倒的 に大きい。 
自然エネルギーによる発電プラントは，燃料に 係わるプロセスがないことから，その $\mathrm{CO}_{2}$ 排出原 単位は火力プラントの值に比べて小さい。しか し, 設備の建設と運用によって間接的に放出され る $\mathrm{CO}_{2}$ 量は意外に多く，太陽熱や太陽光の $\mathrm{CO}_{2}$ 排 出原単位は LNG 火力の $1 / 3$ にもなる。

\section{3. 発電プラントの環境コスト}

発電プラントの $\mathrm{CO}_{2}$ 排出原単位は, 火力プラン 卜を除く之, 現在の電源構成から得られる平均值 より小さな值である。すなわち, 原子力と自然エ ネルギーによる発電プラントは, 我が国の電源計 画に導入すれば $\mathrm{CO}_{2}$ を削減するプラントになる。 それでは， $\mathrm{CO}_{2}$ 対策プラントである原子力と自然 エネルギーの $\mathrm{CO}_{2}$ 削減効果は, 経済的に見てどの 程度になるか環境コストを計算してみよう。環境 コストは, 現在の電源構成を基準に, $\mathrm{CO}_{2}$ を $1 \mathrm{t}$ 削 減するに要する費用として次式から求められる。

環境コスト (円 $\left./ \mathrm{t}-\mathrm{CO}_{2}\right)$

ニコスト増分 (円 $/ \mathrm{kWh}) / \mathrm{CO}_{2}$ 削減量 $(\mathrm{t} / \mathrm{kWh})$

$=($ 対策プラントの発電コスト $($ 円 $/ \mathrm{kWh})$

一基準発電コスト $($ 円 $/ \mathrm{kWh})) /\left(\right.$ 基準 $\mathrm{CO}_{2}$ 原単位 $(\mathrm{t} / \mathrm{kWh})$-対策プラントの $\mathrm{CO}_{2}$ 原単位 $\left.(\mathrm{t} / \mathrm{kWh})\right)$

第 I-3 図は，原子力と自然エネルギー，それ に $\mathrm{CO}_{2}$ 回収プラントについて, それぞれの環境コ ストを求めたものである。原子力発電の環境コス トは，検討プラント中で最も小さく 2,700 円/

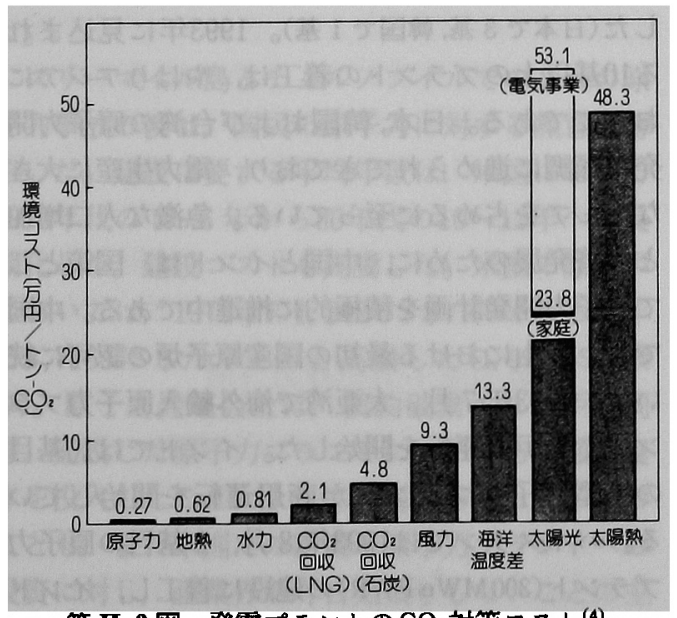

$\mathrm{t}-\mathrm{CO}_{2}$ である。エネルギー密度が比較的大きい地 熱と水力むコストは小さいが, 原子力の值に比べ ると，それぞれ2.3倍と 3 倍になる。 $\mathrm{CO}_{2}$ の回収· 眝溜は，回収に多量のエネルギーを消費し，かつ 設備費と運転費を追加しなければならない。それ は環境コストを大きくし，原子力に比べLNG火 力の併設で7.8倍, $\mathrm{CO}_{2}$ 処理量の多い石炭火力への 併設では17.6倍になる。それに対し，地熱と水力 を除く自然エネルギーの環境コストは，原子力発 電の34〜197倍にあなっている。自然エネルギー による $\mathrm{CO}_{2}$ 削減には膨大なコスト負担を伴うこと を理解する必要がある。

\section{4. 調和と共生が基本}

本稿は,トータルシステムから見て発電プラン トのエネルギー収支と温暖化影響を客観的なデー 夕に基づき定量的に分析したものである。結果か ら, 原子力, 水力, 地熱は, 温暖化影響が最も小さ く, $\mathrm{CO}_{2}$ 削減のための経済負担む小さいことが明 らかになった。しかし，立地問題は導入の共通し た大きな課題である。

自然エネルギーの中で, 太陽光は住宅などの屋 根瓦に電池パネルを設置できれば $\mathrm{CO}_{2}$ の削減効果 が大きくなる。太陽光発電は，昼間に発電できる ピーク用電源で, 電力の負担率の改善や貴重な石 油資源を節約する効果もある。ただ問題は経済性 と供給信頼性で, 太陽光発電の大量導入には大き な経済負担と系統電源の電圧・周波数变動を伴う といった問題があることを理解しなければならな い。太陽光発電だけですべての電源を置き換える ことは非現実的であり，原子力発電す含めて，そ れぞれの特徴を生かして，互いに棲み分けて導入 することが大切である。

\section{一参考文献—}

（1）内山洋司：環境/エネルギー問題から見た原子力発 電の役割, OHM，1992年, 11月号.

(2) 同上：“石油漬け社会”をいつまで享受できるか, エコノミスト，1992年1月28日.

(3) 同上：トータルシステムから見た各種発電プラン トの温暖化影溓, エネルギーフォーラム, 1992年 8 月号.

(4) 同上: 発電プラントの温暖化影響評価, 電力経済 研究 32 号, (1993). 


\section{II-3. 近未来への原子力の展望}

IAEA P. Dastidar, C.W. Hu

\section{1. 世界的に見た原子力の現状}

原子力はすでに各国の電力供給に大きな役割を 果たしている。1992年末には，29ヶ国で424基の 発電プラントが稼㗢しており, その全発電設備容 量は $331 \mathrm{GWe}$ である。さらに，全設備容量 60 GWe の発電プラント 72基が19力国で建設されつ つある。1992年の原子力による電力生産量は2, 027 TWh で，世界の総発電量の約 $17 \%$ 占めた。電 力生産における原子力のシェアは19力国で20\%を 超え，8 力国では約40\%を上回っている（第 II-4 図)。1992年には 6 基の原子力プラントが電力系 統に新たに加わり，1993年にはさらに10基以上が 加わる見込みである。また，アジアの国々では10 基を超える新しい原子力プラント建設が1993年に 着工する計画である。累積運転年数は1992年末で 約6,500基-年に達した。1984年以降，世界全体を 通して原子カプラントの平均稼働率は70\%に近い かこれを上回る值を維持しており，原子力産業の 優れた実績が示されている。

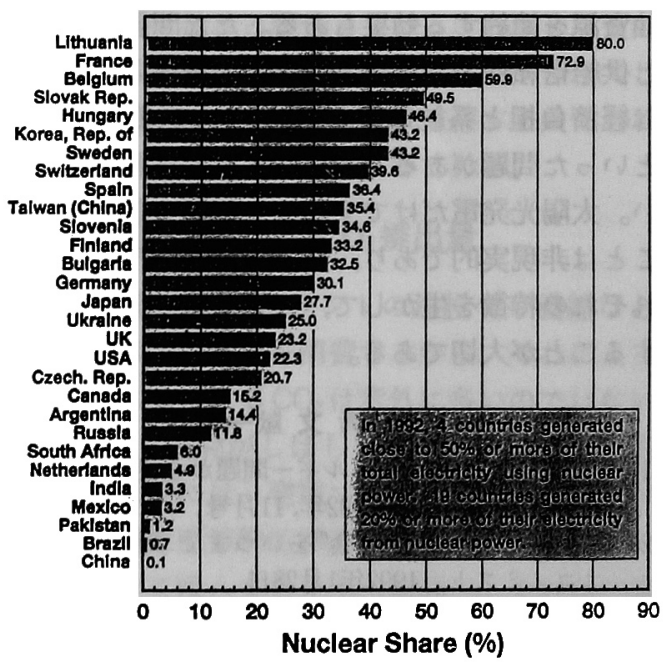

(出典 : IAEA Power Reactors Information System(PRIS))

第 I-4 図 世界の総発電量における原子力 のシェア(1992年)
世界の原子力プラントの $2 / 3$ が北米とヨーロッ パで稼働している。その多くは，エネルギー需要 之経済成長が高水準で推移するとの予測のむと に，1970年代に建設されたものである。しかし， この10年間には，原子力の成長は多岐にわたる要 因のために鈍化した。今世紀末まで原子力の拡大 が継続されるであろう国々は限られている。

中央および東ヨーロッパ(CEE)では，原子力は 大規模に開発されている。電力系統に接続された 原子力プラントは1992年末で64基である。さらに $\mathrm{CEE}$ 諸国では, 原子炉 36 基, 全発電設備容量 28 GWe が現在建設中である。世界で建設中の原子 カプラントの半数はこの地域で数えられる。 $\mathrm{CEE}$ 諸国の原子力のほとんどは, 旧ソ連で設計 されたもの(WWER 型, RBMK 型)で, 例外はス口 ベニアで稼働中の $660 \mathrm{MWe}$ の PWR とルーマニ アで建設中の 5 基のCANDU 炉である。チェル ノブイル事故以降，人々の安全性に関わる関心が 高まった。西側先進諸国および国際的な諸機関か ら，この地域に対して安全確保の技術と金融面で の広い範囲にわたる支援が実施されているところ である。

原子力は西側諸国で停滞しているのに対し，ア ジアの国々にとってはエネルギー供給の有望な選 択肢に見える。ここでは，1992年末には，70基の 原子カプラントが稼働しており，21基が建設中で ある。1991年からの 2 年間では，世界の中で日本 と韓国のみが新たに原子カプラントの建設を開始 した(日本で 3 基, 韓国で 1 基)。1993年に見込まれ る10基以上のプラントの着工は，やはりアジアに おいてである。日本, 韓国および台湾の原子力開 発は順調に進められてきており，電力生産に大き なシェアを占めるに至っている。急激な人口増加 と経済発展のために，中国とインドは，国策とし て原子力開発計画を積極的に推進中である。中国 では, 泰山における最初の国産原子炉の認可に続 いて, 1993年 7 月, 大亜湾で海外輸入原子力プラ ント 1 号炉の運転を開始した。インドでは 10 基目 の小型原子カプラントが商用運転を開始してい る。パキスタンでは1993年 8 月， 2 基目の原子力 プラント (300MWe PWR)の建設に着工し，インド ネシアでは $600 \mathrm{MWe}$ の原子カプラントの実証研 
究が進行中である。さらに多くのアジアの国々 が，自国のエネルギー政策に原子力を導入する計 画であることを表明している。

\section{2. 原子力停滞の原因}

個々の国や地域における原子力開発は，所有す る技術, 経済状況, 環境亡健康への影響, 政策的お よび社会的諸問題などの多くの因子の総体によっ て左右されている。西側先進国における景気後 退，発展途上国における資本不足，CEE 諸国にお ける過渡的状況での困難さ，これらは世界規模の 原子力の展開に対して好ましからぬ影響を及ぼし ている。個々の国々における原子力の政策決定と 展開速度における差異は，これらの国における多 様な状況にその原因がある。そのいくつかは以下 の通りである。

\section{(1) 释剤成長とエネルギー需要}

技術のあらゆる進展は，その製品への需要によ り支配される。原子力は, 経済発展に応じ必要之 なるエネルギー需要のうち, ベースロードの電力 を生産する。1960年代と70年代のはじめの時期, 米国での電力需要は急激に膨脹し, 数多い原子炉 が建設·発注された。1970年代半ば以降，経済成 長の減速とエネルギー利用効率の向上によって電 力需要の伸びは，年率 $7.2 \%$ から $2.5 \%$ に低下し た。その結果, 多くの原子力および火力プラント の契約は破棄され，すでに着工していた原子力プ ラントの建設は実際には延期されることとなっ た。

スリーマイル島とチェルノブイルでの 2 つの原 子力事故の後は，国民の原子力に対する熱意屯薄 らいだ。建設に要する平均年数は，米国において 1970年代の 5 6 年から 80 年代の $10 \sim 12$ 年へと長 期化した。建設コストむ高騰した。米国の原子炉 においては，1976年の 1,242 US \$ $/ \mathrm{kWe}$ から86年 の3,716 US $\$ / \mathrm{kWe}$ 一之高騰した (1, 990 US \$換 算)。原子力発電会社は，契約破棄された炉之同 様，建設した原子力プラントについても巨額の資 本を投入したことによって，痛手を被った。この ことも，また米国での新規な原子カプラントへの 投資に対し，産業界が今日気乗りしないことの主 な理由の 1 つである。

\section{（2）技術の開発}

原子力には高度の技術的要請がある。原子炉設 計の標準化と同一化を目的として，事業者, メ一 カーと規制担当の 3 者の協力のむとに, 設計, 建 設と運転に関わる多くの経験が集積され，共有さ れ，かつフィードバックされなければならない。 米国では，標準化されていない設計と許認可の煩 雑な手続きのために，フランスに比べより多くの 原子カプラントを建設したにもかかわらず，原子 力産業の利益は少ない。非標準化は規制之許認可 のリードタイムにあ影響を及ぼしている。

安全上, 経済上の一層の要請に応えるため，改 良型原子灯の開発が多くの国々で進められてい る。新規に改良された原子炉が21世紀初頭の前後 において商業的に利用可能となるものと期待され ている。

\section{(3) 原子カのコスト}

資本が不足している多くの開発途上国にとって は，巨額な資金を必要とすることが原子力開発ブ ログラムの導入を困難なものとしている。例え ば，中国とインドでは，策定した原子力開発プロ グラムへの資金確保が困難な状況にある。

運転と保守のコストは，米国では1980年から89 年に実質的に約 $7 \%$ 増加した。このため，火力プ ラントに対する原子力の経済的優位性が損なわれ てしまった。

経済性に対するすう一つの重要な影響は，世界 的な景気の後退によって化石燃料の価格が急激に 切り下げられたことによってもたらされた。U価 格も低迷したものの，火力プラントとは異なり， 原子力プラントでは電力価格に占める核然料費の 割合はほんの少しでしかない。

いくつかの(米国の)地域では現在電力供給能力 が過剩であること，安価な代替電力源が入手可能 であること，運転保守コストの上昇および(安全 確保のために)要求される付加的な設備などを考慮 して，事業者側が実施したコスト解析の結果，ヤ ンキー,トロージャンとサンオノフレ 1 号炬など 数基の原子炉の早期閉鎖が決定されたのである。

(4) 公衆の受容

スリーマイル島とチェルノブイルでの原子カプ ラント事故以降，公衆の原子力に対する関心は高 
まった。2つの事故を教訓として, 原子力プラン 卜の安全水準を改善するため, 一層厳格な要請が 原子力規制に取り入れられた。いくつかの国々で は, 公衆の反対が原子カプロジェクトの遅滞ない し破棄につながった。公開ヒアリングと許認可手 続きの長期化は，原子カプラントのコスト上昇と 原子カプロジェクトへの投資家の邀巡をるたらし たのである。公䍃の理解が得られなければ，原子 カプラントと放射性廃裹物の永久処分のための立 地は一首困難なるのになるであろう。これは原子 力開発をさらに阻害しか好ない。

\section{3. 原子力の潜在的役割}

世界的な人口增加と経済成長は，エネルギーの 需要の増大を引き起こしつつある。1990～2010年 の間に世界のエネルギー需要は50\%程度増加する あのと見積もられており，電力需要は1990年から 2010年の間に 2 倍に増加するであろう。多数の老 朽化した発電プラントは閉鎖され，新しいプラン トによって代替されなければならない。エネル ギー節約と効率の改善は, エネルギー供給体への 増大しつつある需要のわずかな部分を埋め合わせ るにすぎない。水力を除けば，再生可能エネル ギ一資源を大きな規模で利用するためには，なお 多大な開発努力が必要である; 近い将来に重要な ブレークスルーを達成できるという兆候は見られ ない。化石燃料による発電は当分の間, 主要な電 力生産源であり続けるであろう；けれども，環境 への意識の高まりによって, 硫黄酸化物および窒 素酸化物の放出を削減するために, 新しい“ク リーン゙な技術の開発と既存の火カプラントの改 善が要求されるようになってきた。そのような開 発が実現しても，なお化石燃料の燃焼に伴う $\mathrm{CO}_{2}$ の排出は重大な髹念の的として残されている。

原子力のみが, ベースロード発電として火力発 電に対して経済性を持った, 大規模な投入が可能 な唯一の非化石エネルギー資源である。原子力の 環境保全上の優位性は, 最後には公衆に受容され るに違いなく，エネルギー戦略のための政策決定 に影響を及ぼすに相違ない。原子カプラントの稼 働によって，すでに $\mathrm{CO}_{2}$ の放出を $7 \%$ (世界全体と しておよそ 5 億 3,000 万 $\mathrm{t} /$ 年の炭素に相当する)削減さ
せることに貢献している。多くの国々では，環境 保全のために施設改善を追加する要求と $\mathrm{CO}_{2}$ 放 出税の提案があり, 化石燃料資源による電力生産 はこれまでよりあコストが押し上げられる可能性 が出てきた。これによって原子力が，より経済的 に優れた選択肢であるよみなされるようになるで あろう。

原子力は，国際収支, 経済発展, 化石燃料価格の 安定化, エネルギー供給の保障と多元化など, 一 国の社会経済全体に対して強い影響力を持ってい る。例えば,日本での検討によれば,むし世界で原 子力が, 即刻であれ, 10年以内に段階的にであれ， 終息されるならば，石油と石炭の価格は2005年ま でに1990年価格の 2 倍に上昇するという。日本や 韓国のようにエネルギー供給の海外依存度の高い 国々では，長期にわたりエネルギー供給を確保す るために原子力が不可欠の選択肢なのである。

OECD/NEA とIEA がIAEA 等と共同して奏施 した電力価格の動向予測に関する調查から，化石 燃料資源を産出または安価に入手できる国は例外 として,多くの国々では2000年の時点で,原子力に よる発電価格は石炭火力のそれを下回るものと見 積むっていることが明らかになった(第 I-5図)。

世界の原子力の成長に関する予測がIAEAに よって取りまとめられた(第 II-6 図)。低成長の ケースでは，2015年までの原子力発電の伸びは $13 \%$ あり，現在の原子力開発の停帯が持続する 場合である。このケースでは, 電力需要を満たす ために多くの国で石炭火力と天然ガス火力が採用 されるだろう。高成長のケースでは，2015年まで に世界全体で原子力発電設備の伸びは約70\%とな るであろう。この場合, 東南アジア諸国での原子 力の発展, 西ヨーロッパでの原子力の復活, 北米で の復調およびCEE での計画通りの建設を予想し ている。

\section{4. 今後の原子力発展の方向}

持続可能な繁栄を達成し環境問題を紘和しつ つ，世界のエネルギー需要の拡大を満たすために は，あらゆる種類の技術的選択肢を適切に組み合 わせることが必要不可欠である。原子力は $\mathrm{CO}_{2}$ を放出しない選択肢の一つであり, 商用化され, 


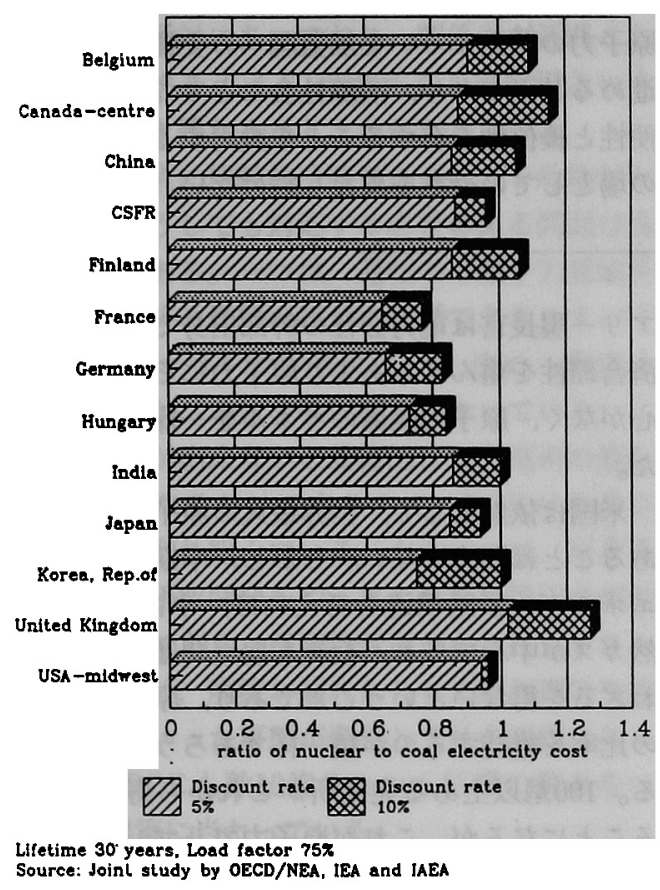
第 II-5 图 石炭火力を5 10\%下回わる
原子力の発電価格

経済性を有する主要な電力生産の手段である。

原子力開発の進展は包括的な政策決定が行われ ることによって可能となるであろう。この政策決 定は, すへてて種類のエネルギー連鎖における健 康と環境へ及ぼす影響を総合的に比較して，長期 にわたる首尾一貫した原子力プログラムを導くあ のとなろう。許認可プロセス, 立案, 効率的なプロ ジェクト管理, 標準化, 系統的な配備, マンマシン インターフェースなど数多くの項目を抜本的に刷 新させることによって, 原子カプラントの建設期 間の短縮と，より優れた運転管理が可能となり, 実質的な経済上の利便があたらされるであろう。

安全性之放射性廃棄物の処理処分は，公衆が原 子力を受容するための鍵となる事項である。現世 代の原子カプラントは，実証された工学技術のあ とに高度の安全水準を保つように，多くの国で設 計・運転されている。CEE諸国内の原子力プラン トについての国際的な安全性評価は，これらのプ ラントの安全性を高めることを目的としたすので ある。専門家によれば, 高レヘル廃棄物の地層処

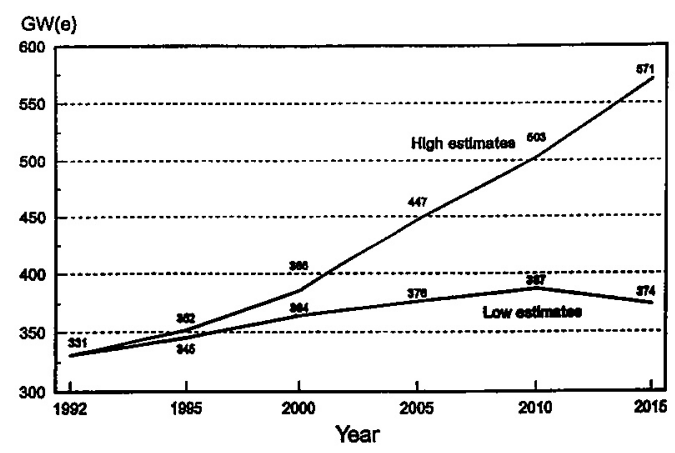

(出典 : RDS-1, 1993 ed.)

第 I-6 図 世界の原子力発電成長の予定

分は技術的には実証済みと考えられている。しか し，放射性廃裹物の永久処分を実現するために は，なお公衆の合意など解決すべき事項が残され ている。

実証された技術と蓄積された経験とに基づい て，改良型原子炬が提唱されている。既存の原子 カプラントのすでに害績のある経済性と運転成績 をさらに改善するため，技術の改良が進められて いる。AP600, ABWR, SBWR, EPR, CANDU3な どの改良型炉の設計は世界的に進展している。改 良型炉の主な特徵には, 受動的安全性, 広範な標 準化とモジュール化，燃料の高性能化が含まれて いる。これらすべての進歩は次世代の原子力プラ ントの建設期間の短縮, より高度の安全水準, より 優れたプラント実績と有意なコスト低減を可能と するであろう。先進諸国の大型炉の改良と並行し て, 中小型炉の開発により, 電力系統が小さい, 電力需要の伸びが小さい, あるい資本が不足し ている国々や電力会社において, 原子力の利用が 促進されるであろう。改良型原子炬の導入は世紀 の変わり目ごろ実現するように思われる。それは 世界の原子カプログラムの拡大に道を拓くあの之 なるだろう。

IAEA は，個々の国のおかれた社会的, 経済的 および環境上の問題に配慮しつつ, 国のエネル ギー戦略の策定における原子力開発計画に対し て，数多くの技術支援プロジェクトを実施してき た。IAEA は, 情報交換, 国際安全基準の設定, そして専門家使節団の派遣など多数の方法によっ 
て安全性の確保を推進してきた。旧ソ連の設計に よる RBMK 型炬と WWER 型炬の安全対策に関 する総合的安全性レビューは，CEE諸国に非常 に役立っている。IAEA は, 地域を問わず国際的 にさらに安全性を確保するため，原子力安全国際
条約(の策定)について取り組んでいる。IAEA は, 原子力の開発にっいて加盟国への支援を引き続き 進める計画であり，国際社会にとって原子力が利 便性と優位性を有することを説得するため，議論 の場としての役割を果たし続けたい。

\section{I-4. 新政権下の米国原子力政策}

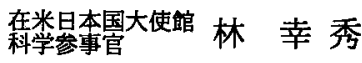

クリントン大統領が米国の大統領となって 1 年 余が経過した。当初はなかなかエンジンが掛から ない様子であったが，ここに来てようやく重要問 題についても政策を出し始めており，4年ある任 期のこれからが本番というところである。

赤字削減, NAFTA (北米自由貿易協定), 健康保健 改革といった問題が山積する中で，クリントン大 統領の原子力に対する問題意識は，それはど大き なあのではない。前回の民主党政権であったカー ター大統領の時には，核不拡散か政権のプライオ リティの高い問題であり，したがって我が国を含 めて世界に対し，米国の原子力政策がいろいろ影 響を与えた。今回はカーター政権のような派手な 動きはないと考えられるが，日本にとって米国の 動向は依然として重要であり，本稿では，研究開 発利用の面之核不拡散の面とに分けて述べてみた い。

\section{1. 原子力の研究開発政策}

原子力の研究開発については, クリントン大統 領は消極的である。昨1993年初めの大統領一般教 書の演説において，大統領は連邦予算赤字削減を 押し進める決意を表明したが，削減しなければな らない代表的なものとして原子力研究を挙げた。 元々の原稿には原子力研究という字句はなく，ク リントン大統領のアドリブとわかった。大統領の 頭の中に，原子力研究が不要なものの代表として 刻まれていたことになる。DOE(米国エネルギー 省)であ同様で，ワトキンス前長官は原子力研究 に理解があり，自分の部屋に原子炉や海軍出身ら しく原子力潜水艦のパネルを並へてていたが，オレ
アリー現長官は電力会社の幹部出身で，短期的経 済合理性を重んずるあまり原子力にそれほど同情 心がなく，原子力関係のパネルを一掃してしまっ た。

米国は依然として，世界最大の原子力発電国で あることは間違いない。しかし，中期的な米国の エネルギー供給構造を考えれば，やはり石油, 天 然ガスが中心であり，石炭も雇用問題を抱えて使 わざるを得ないということであり，原子力は現在 の比率を維持するのが精一杯であろうと考えられ る。100基以上ある発電所がこれから寿命を迎え ることになるが，これが原子力でリブレイスされ るかどうかですら疑問であるといわれている。し たがって，既存の軽水炬を中心とした研究開発に 重点が置かれることとなり，軽水灯の安全性の一 層の向上や経済性の改良といったことが，ここ当 分の主要テーマとなっている。

DOE の研究所は，質・量ともに世界で最先端の 原子力研究を行なってきたが, 軍事研究のニーズ の低下·競争力の強化といった観点から，軍民転 換・ハイテク化がスローガンとなっており，その 方向に合わない大部分の原子力研究開発が縮小さ れることになる。核融合は八イテクということに なっており，今後とも積極的に推進すべきである と位置づけられているが，高速炉は怡々たるあの である。高速炬は元々カーター政権の時にクリン チリバー原型炬の建設を中断して以来, 米国での 研究は非常に困難なむのとなっており，関係者が いろいろ知惠を出して目立たない形で細々と研究 を継続してきた経緯がある。しかし，それす見逃 して鿓えなくなっている。混合酸化物然料を使う FFTF(米国ハンフォード研究所)は, 地元ワシント ン州の強い運転継続の声を受けつつも, 現在運転 を中止しており施設廃止となる恐れが強い。 また，金属燃料を使う IFR(米国アルゴンヌ研究 
所およびアルコンンヌ・ウエスト研究所) 屯議会や DOE 内部の強い反対にあっており, 関係者が活路とし て考えたアクチナイド・リサイクル研究用という ことであ生き残れるかどうかわからない。

原子力研究に比較的冷淡なクリントン政権にお いてむ, よ゙うしても対応する必要のある問題は廃 裹物対策である。一つは, 運転中の原子力発電所 からの使用済み燃料の処分の問題である。ネバダ 州のユッカマウンテンをサイトと決め，調查に 入っているが，地元の強い反対にあっている。し かし，これが出来ないと最終的には発電所の運転 が出来なくなるわけであるので，DOE は最重点 課題として取り組んでいる。すう一つは，核兵器 製造関連の研究開発をやっていた施設周辺の環境 回復の問題である。廃棄物管理が余りにもずさん であったため, 廃液が漏れたりして周辺環境を污 染させたといった事態が発生して社会問題になっ ている。DOE む数 10 億 \$という巨額の資金をつ ぎ込み，対策に当たっている。

我が国の原子力研究開発は，米国から資材や技 術の提供を受け，米国の研究所に指導を仰いで成 長してきたといえる。現在であ，いろいろな形で 存在している協力関係が, 我が国の研究活動の重 要な糧になっている。しかし，上記のように米国 での研究開発は，DOE 金下の研究所を中心に大 きく変わりつつある。むし原子力の研究開発を進 める上で，従来之同様に米国側からの刺激を求め ていくとすれば，米国の研究所の変化する行方を よく見極めていく必要がある。

\section{2. 核不拡散政策}

日本はこれまでに，米国の核不拡散政策の変更 で随分痛い目にあってきている。1977年にカー ター大統領が政権についた際，インドの核実験に 端を発した世界的な核不拡散の流れの中で, 非常 に厳しい核不拡散政策を発表した。このため我が 国においては試運転中だった動燃の東海再処理工 場の運転をめぐって激しい議論が行われたり，日 本の電力会社が英仏に使用済燃料を移転する際の 米国の同意取付けが大変難航したことは記憶に新 しい。

昨年 9 月, 国連総会の演説の中でクリントン大
統領は，増加する高濃縮 Uと $\mathrm{Pu}$ の蓄積がテロリ ズムの危険を増大させていることに触れ，核兵器 用の $\mathrm{Pu}$ 等の物質の生産禁止を目指す国際協定作 りを提案した。この演説と共に，ホワイトハウス は次のような提案を含むファクトシートを発表し ている。

- 核爆発目的あるいは国際的な查察下に ない高濃縮UおよびPuの生産を禁止す る国際的な条約を提案する。

- 政治的に不安定で核拡散の危険の大き い地域で，核物質生産を制限する地域取 決めを促す。

・すでに核抑止に必要ない米国の核物質 をIAEA の保障措置に委ねる。

- 旧ソ連の解体核兵器からの高濃縮Uを 購入し，平和目的の原子炉燃料に転用す る。

・ 民生用の $\mathrm{Pu}$ 蓄積を制限する手段およ び民生用高濃縮 Uの使用を最小化する 手段を模索する。

- $\mathrm{Pu}$ 処分に関し，包括的かつ長期的な オプションを調查する研究を開始する。

- 米国はPuの民生利用や再処理を推奖 しない。しかし，米国と西ヨーロッパ諸 国および日本との間にすでに存在する民 生用原子力計画の中での $\mathrm{Pu}$ 利用につい てのコミットは維持する。

若干の説明を加えると，国際条約については， 不平等条約を理由に NPT(核不拡散条約)に入って いないインド,パキスタン等を取り込んで, NPT を補完する形で核不拡散の実を挙げようという提 案と考えられ，我が国としても条約検討に積極的 に対処する必要がある。地域取決めについては, 現在大きな問題である朝鮮半島等の地域での核拡 散の危険に対し，例えば非核地帯化構想的なこと を推進しようという意図と考えられる。米国の $\mathrm{Pu}$ をIAEA 保障措置の下に置くという提案は, 1995年の NPT 期限切れを控え，非核兵器国に根 強く残る不平等論を出来るだけ和らげることによ り，NPT延長を目指すむのであろう。

最後の点が，我が国にとって一番の関心事であ る。今回の政権が発足した後, 我が国の関係者は 
カーター政権の時の苦い経験を想起し, 新政権が どのような政策を打ち出すか米政府関係者に尋ね た訳であるが，その際の米政府の基本的な応答ぶ りは，前政権と此へ核不拡散への取組みがより厳 しくなることは事実であるが,すでにコミットし たあのまでひっくり返すことはしない，というす のであった。今回ファクトシートという形で確認 された訳であり, 我が国のPuリサイクル推進の 観点からは喜ばしいことと思う。

しかし,グレン上院議員を初めとして米国議会. マスコミ等には, 日本のPu利用に対する根強い
反対があり，これがいつ，どのような形で反撃に 出るか予想できない面がある。また，米政府の中 にも，今までの行きがかり上認めることはやむを 得ないが，どうして日本は経済合理性のない $\mathrm{Pu}$ リサイクル路線を強行するのかという疑問を我々 に投げ卦けて来る人もいる。このような議会・マ スコミの反対を阻止し，政府関係者の疑問を解い ていくためには，我が国におけるPuリサイクル が単なる計画でなく，本当に実施されるものであ るということを着実に示して行くことが重要と考 えている。

\section{CIS, 東欧に関する諸問題}

\section{III-1. チェルノブイル事故後の 状況之課題}

東京大学医学部 青木芳 朗

\section{はじめに}

1986年 4 月26日に発生したチェルノブイル原子 力発電所の事故から 7 年が経過した。1990年には IAEAによる污染地域住民の健康影響調查が行わ れ，WHO(世界保健機関)による国際研究総合セン ター設置計画等が実現に向けて努力されている。

チェルノブイル事故による人体影響はおおまか には，(1)事故時に消火・除染活動等を行なった人 達の急性障害と晚発障害, (2)污染した地域に住む 住民達の健康影響とがん発生の増加，(3)移住した 人達の心理状態の 3 つに分類される。

本稿では，これら 3 つの事項について概説する と共に, チェルノブイル事故を他山の石として, 我が国の緊急時被曝医療の面ですみやかに解決す べき課題を略記する。

\section{1. 事故時に消火・除染活動を行なった 人達の放射線影響とその対策}

事故時に消火・除染活動を行なった人達のなか で, 現場で緊急医療を受けた被災者は225名以上 とされ，うち急性の健康障害を受け治療を要する と判断された者は147名で，4名が現地で死亡し
ている。そのうち115名がモスクワ第 6 病院に移 送され治療を受けた。27名が死亡し，その内訳は 放射線熱傷での死亡19名, 腸管死 2 名, 骨䯣死 6 名 である。骨䯣移植が 13 名, 胎児肝血液細胞移植が 6 名に施行された。

死因の多くは $\beta$ 線被曝による放射線熱傷で，消 火の際に放射能を含んだ水により服が濡れた状態 のまま作業を続けたためと考えられている。

骨䯣障害に対して, 両親・兄弟からの同種骨檤 移植13例, 胎児肝血液細胞移植 6 例が試みられた が, 残念ながら不成功に終わった。

モスクワ第 6 病院は, 事故発生から 2 時間後に は事故の通報を受け，直ちに救護班を編成して同 日の早朝には現地に到着している。事故の12時間 後には，医師団に物理学者む加わり，被災者の選 別が行われた。そのうち，モスクワ第 6 病院での 入院措置が必要な患者は, 24時間以内にモスクワ まで般送されている。

\section{IAEAによるチェルノブイル 健康影響調查}

チェルノブイル原子力発電所 4 号炉の事故は, 周辺住民のみならず隣接 3 共和国の住民の健康不 安を引き起こした。ソ連政府は，事故後直ちに緊 急医療を行うとともに, 発電所周辺 $30 \mathrm{~km}$ 圈の住 民の移住を強行した。しかし，実際には正確な情 報の不足のため，住民の不安は増大した。

そこでソ連政府の要請により，IAEAによる国 際チェルノブイル・プロジェクトが開始された。 
医学分野における本プロジェクトの目的は, 事故 発生後 4 年を経過した1990年における隣接 3 共和 国の污染地域住民之污染の少ない居住地域住民の 間の健康状態の差を発見することであった。

\section{(1) 調查の実際}

健康影響タスク・グループでは，世界各地から 参集した医学専門家がロシア共和国, ウクライナ 共和国, 白ロシア共和国に分かれ，それぞれ下記 の通りの健康診断を行なった。

対象污染居住地区の設定は, ${ }^{137} \mathrm{Cs}$ の污染状況 を参考にして, 高濃度污染地域と低濃度污染地域 を選択した。

健康診断対象者は, 2 歳児, 5 歳児, 10歳児, 40歳 成年, 60歳成年とした。2 歳児では, マスコミに あ報道されている鉛中毒による分血の有無の検 討, 2 歳, 5 歳, 10 歳児では, 事故後の栄養状態の 悪化による成長の遅延の有無の検討がなされた。 5 歳児では，事故時の放射性ヨード摄取の影響, 10歳児では甲状腺疾患の発見が主目標であった。 40歳, 60歳成人には，いわゆる成人病に対する影 響の検討を行なった。このように，これらのグ ループ分けは予想される臨床的健康影響を発見で きるように考慮された。

甲状腺については，甲状腺の専門医が全例を診 察し，超音波診断装置によって甲状腺の大きさ， 腫瘍の有無をチェックした。

\section{(2) 調查結果}

調査された子供たちは一般に健康的であり，污 染地域, 対照地域之も体重・身長の増加, 分血, 血中 鉛濃度,甲状腺ホルモン等際立った異常はなく地 域差もなかった。また血中鉛濃度は正常範囲に あった。

成人の検診では，がんや高血圧, 甲状腺疾患等 が污染地域, 対照地域の住民ともに認められたが， 両地域での差は発見できなかった。甲状腺の結節 は, 污染地域, 対照地域の住民ともに $15 \%$ に認め られたが，これは諸外国の報告に類似していた。 なお，甲状腺の結節は，必ずしもがんではないと いうことを付け加えておきたい。

事故後 4 年経過の時点での調查であったので, 白血病の增加が㒻念されたが, 今回の調查対象者 には, 白血病患者は 1 例6なかった。しかし、こ
の問題には今後の注意深い観察が必要になろう。 アンケート調查の結果から，住民が放射線被曝 に対して不安を抱き，また移住に対しても不安を 抱いていることがわかった。自分の病気は放射線 が原因と考えている人が多い。

\section{(3) 指摘された問題点}

正確なあるいは適切な情報の不足からくる不安 や健康影響は無視できない。移住を決める前に， 移住したあるいは移住するという状況变化から来 る健康影響す考虑に入れるべきである。一般的な 健康診断の継続はすべきであるが，甲状腺吸収線 量の多いと推定された子供たちは特別な診断調查 体系を構筑すべきである。

医学・診断機器の整備, 医療消耗品, スペア部品 の入手等の可能性を高める必要がある。線量測 定, 疾患の診断基準等の国際化が必要である。

\section{WHOによる国際研究計画}

WHOは，下記の 5 つの目標を揭げて，国際的 な研究機関を発足させることを決定した。

（1）より正確なチェルノブイル事故による健 康影響の評価のための被曝線量の再評価。

（2）現在および将来における，特に子供たち に対する被曝あるいはその他の影響。

（3）事故による健康影響を最小にするための 方策の決定。

（4）社会的・精神的状態の悪化の解消策。

(5) 放射線による健康影響を他の原因から区 別する。

これらを実際に研究するために，ロシア共和国 のオブニンスクに国際研究センターを建設し，支 所としてロシア共和国のブリアンスク,ウクライ ナ共和国のキエフ,ベラルーシ共和国のゴーメル (ミンスク?)に研究所を建設する予定である。寒 際の研究は 3 共和国の研究所で行い，センターは それらの調整を行うことになる。

\section{4. 事故後のがんの発生状況}

1991年11月号の Lancet 誌に白血病の增加に関 する論文が出されている。それによると，65歳以 上の高年齢者では1987年に突然白血病の発生率が 增加し, その後む事故前に比して $2 \sim 3$ 倍の発生 
率を保っている。このことは，事故後にはがんに 対する関心が高まり，受診率, 発見率が高まった ためと考えられる。1992年 9 月号の Nature 誌に 掲載された科学書簡に, ベラルーシにおける子供 の甲状腺がんの増加が報告された。ゴメル地域に おいて，1990年以前には $1 \sim 2$ 例しか甲状腺がん の発生がなかったが，1991年には38例に増加し， この増加はチェルノブイル事故によるものであろ うとしている。しかし，この論文に対しては，重 松らが甲状腺への被曝線量が明らかでないこと， 地域の人口に対する甲状腺がんの発生率との比較 はどうか等の異論が出されている。

おわりに

チェルノブイル事故は確かに大事故であるし，
人類の健康にあ様々な影響を及ぼし，また将来及 ぼすかむ知れない。だが我々研究者は，事故は事 故として冷静に受け止め, しかる後に今後の対庆 を誤らないようにすべきである。

チェルノブイル事故を他山の石として，我が国 の緊急時被曝医療の体制を見直し，再構筑しなけ ればならない。事故発生時には訓練を受けた医師 -看護婦 (士)・放射線技師等や救急医療の専門家が 直ちに臨戦体制に入れなければ，緊急ということ で駆り出された医師等の間にいたずらに不安を引 き起こすことになる。すなわち，緊急時被曝医療 に携わる医療スタッフの平常時の養成が重要とな る。国および関係諸機関の熟虑と実行を促した い。

\section{III-2. ソ連崩壊に伴う余剩核物質・ 頭脳流出·核廃棄物問題}

\section{日本原子力研究所 舘 野 淳}

「核抑止論」に基づく，核の引き金に手を掛けた 米り対峙の状況のもとで，核兵器の総量は人類を 何回す絶㙎するに足りるほど膨れ上がった。ちな みにピーク時の核弾頭 (warhead +bomb) 数付米国 32,000 , ソ連 45,000 発といわれる(1)。こうした際 限ない核軍拡競争の重厌が原因の一っとなって, ソ連が崩壊した現在, 過去の軍拡競争の「つけ」は 旧ソ連圈内だけでなく地球規模で広がりつつあ る。このような問題をわれわれはどう考えたらよ いのだろうか。まず事実関係から見てみよう。

\section{1. 核兵器削減と余剩核物質}

1991年 7 月および93年 1 月に調印された戦略核 兵器削減条約(START-I，II)によって，米口それ ぞれ 17,000 と 33,000 発の現有核弾頭(文献(1)によ る。ただしロシアの数值については資料により大きな へただりがある)を2003年までに削減し，戦術核兵 器を全廃, 戦略核兵器をおのおの 3,000 から 3,500 発にするとの合意が成立し，現在双方とも年間約 2,000発のペースで，解体作業を進めつつある。1
個の弾頭中には平均してPu の場合 $3 \sim 4 \mathrm{~kg}$, 高 濃縮Uの場合 $15 \sim 20 \mathrm{~kg}$ が含まれており，ロシア ですでに解体されたとされている約10,000発の分 も含めて, この廃棄作業によって, 高濃縮Uで $500 \mathrm{t}(\square)+400 \mathrm{t}$ (米), Pu で $100 \mathrm{t}($ (口) $+50 \mathrm{t}$ (米)の 余剩核物質が生じることとなる(2) (ロシアの高浱縮 $\mathrm{U}$ が1, 000t, 米国のPuが100tという推定もある $\left.{ }^{(3)}\right) 。$

これらのうち高濃縮Uに関しては，天然Uで 薄め, 低濃縮 Uとして軽水炬燃料に利用するの が最む現実的な処置法というべきであり，現に米 国は500t の高濃縮 Uをロシア国内で低濃縮 U と して，これを20年にわたって合計 120 億ドル(低擞

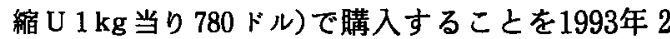
月取り決めた。これは全世界の原子力発電所の 2 年分の燃料に相当する。米国の高濃縮 U も同様 にして処置されるであろう。問題はPuである。

$\mathrm{Pu}$ は同位体で薄めるというわけにはいかず, したがって，なんらかの方法で燃料に加工したと してす，化学的手段で比較的容易に純粋な Puを 取り出すことが可能であり，核拡散上の㗹念を払 拭することができないからである。Uと混ぜて MOX 燃料として軽水炉あるいは高速炻で利用す ることは可能であるが，原子力発電によって発生 する $\mathrm{Pu}$ (核兵器級 $\mathrm{Pu}$ とは同位体比が異なるが,「粗雑 な核兵器は製造可能とされる)の扱いにさえ四苦八 
苦している現状では，とても余剩 Pu まで民生用 として利用することは困難であろう。いっそのこ と，ガラス固化などの処理をして高レべル廃棄物 として処分してしまえという主張もある(2)。いず れにしても，解体によって生じたPu は当面厳重 な監視の下に安全に保管される必要がある。

\section{2. 頭脳流出問題}

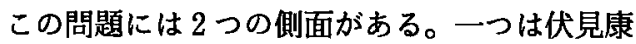
治元日本学術会議会長がその支援を呼び掛けてい るように(4)，帝政ロシア時代および旧ソ連時代を 通じて権威をむっていたロシアアカデミーが政治 的混乱の中で無力化し，多数の科学者が生活にも 困り，その結果生じた国外流出の問題であり，今 一つは核兵器を中心とした軍事技術のスペシャリ ストの流出, 同技術の拡散の問題である。旧ソ連 時代のいわゆる封鎖都市といわれるチャリアビン スク 65 (-40に同じ。Pu生産)-70(核弹頭組み立て), トムスク -7 (U 濃縮, Pu生産), アルザマス-16(核弾 頭組み立て),クラスノヤルスクー26(Pu生産)などに 詳しい知識をもつ専門家約 2,000 人がおり，その うち数人が流出しても大問題といわれる ${ }^{(5)}$ 。この 問題は国際間で対策が検討され，異例ともいうへ き早さで協議が整い，わが国は 2,000 万ドル，米 国と EC がそれぞれ 2,500 万ドルを拋出して, 1992年12月流出防止のための国際科学技術セン ターが設立された。しかし，ロシアでの批准が遅 れ，まだ実質的に機能していない状態である。

\section{3. 核廃棄物問題}

最近，原子力潜水艦の原子炉などを含む核廃棄 物の海洋投棄が継続して行われていたことを示す ロシア政府調查委員会の報告書 ${ }^{(6)}$ が発表され，多 くの人々に衝撃を与えた。同報告書によると, 日 本海への投棄は液体廃棄物約 $12,000 \mathrm{Ci}$, 中低レ ベル固体廃棄物約 $4,000 \mathrm{Ci}$ であるが，北極海には 使用済み燃料を入れたままの原子炬など230万 $\mathrm{Ci}$ が投棄されている。日本政府は調查船による日本 海での放射能調查を行い,「特段の異常は認められ ない」との結論を下した。しかしながら，投棄地 点での調查は行われておらず，ロシアの当事者も 今後投裹を一切行わないことを言明しているわけ
ではないので，より詳細な調查と対策, 投棄禁止 に向けての今後の対応が求められている(7)。

旧ソ連では，これまでにも核兵器関連放射性廃 棄物の大量投棄や大規模な環境污染が発生してき た。1957年チャリアビンスクの再処理工場や Pu 生産炬などからなるマヤーク・コンビナートの放 射性廃棄物眝蔵施設で大爆発が発生し2,000万 Ci が環境に放出された。メドベージェフが告発した 「ウラルの核惨事」である。同コンビナートは1951 年以前は高レベル廃棄物を付近を流れるテチャ川 にそのまま放出し(合計270万 $\mathrm{Ci}$ )，その一部は北極 海にまで達した。その後, 川への放流は止めて同 じく付近のカラチャイ湖に 1 億 2,000 万 $\mathrm{Ci}$ を捨て たが，1967年の干ばつで湖は干上がり，風が放射 能を巻き上げて周辺地域を広範に污染したとされ $ろ^{\left({ }^{(8)}\right.}$ 。セミパラチンスク核実験場付近の深刻な住 民被曝の実態も伝えられている。このような事態 の流れから見れば，上述の海洋投棄はなにす特異 な出来事ではないのかすしれない。

\section{4. 核軍拡競争は何をもたらしたか}

止まるところを知らなかった核軍拡競争は，幸 いにしてこれまでのところ第三の広島・長崎の悲 劇は生み出さなかったが，代わりに，あり余る $\mathrm{Pu}$ や大量の軍事科学者の失業と, 深刻な環境污染や 住民被曝を生んだ。ソ連は国家が崩壊したために その影の部分がわれわれの目にはっきりと映る が, 本質は米国も変わらない。DOEもまた軍事利 用の核廃棄物の後始末に追われることになった。

米ソ対決の冷戦時代は終わり，今後の国際政治 の最大の課題は, 地域紛争やテロリズムなどの, いわゆる低強度戦争 (low intensity conflict)にい かに対処するかにある，という考え方がある。こ うした考えからすれば，核拡散や頭脳流出は最大 の危機といえる。国際科学技術センターが極めて 短期間で設立されたのあこうした考えが背景にあ るあのと思われる。しかし考えてみると，この考 え方は治安維持的発想法である。治安を維持する ことは大切だが，それだけでは問題の本質的な解 決は得られない。

最近クリントン大統領は核拡散防止をさらに厳 しく追及する方針を打ち出した。それならば同時 
に，核保有国の核を同じゥェイトでゼロにするこ と(核兵器の廃絶) す䈌しく追及すべきである。北 朝鮮の核は悪で, 米国の核は善であるという論理 は成り立たない。

ロシアの物理学会会長セルゲイ・カピッッアは， 「低い給与, 無給, そして今は侮辱されているーソ 連の科学者たち」という題で, 頭脳流出問題につ いて「どこかの独裁者に自分を売るかどうかは, お金の問題ではなく個人的, 職業的誠実さの問題 だと思う」と述べ，さらに「アルザマス-16のよう な研究機関が新しい目的の研究機関に再生するこ とは容易ではない」「われわれは若い頭脳を研究 に引き付けることに成功していない」「「䒔ロ あ述へていたように，かつては創造的な研究者た ちが軍事的研究開発競争に参加していたが，それ あ過去のあのとなってしまった。なぜならば大目 的が失われてしまったから」と述べている(9)。こ の言葉は，職業的誠実さとはなにか，それは誰に
対する誠実さなのか，また科学者が軍事に奉仕す るということはどういうことなのか, いろいろと 考えさせられるあのを含んでいる。

\section{一参考文献—}

(1) Nuclear Notebook:Bull. At. Sci., 49[4], 48 (1992).

(2) von HippeL, F., et al. : Scientific American, p.32, Aug. 1993.

(3) 中島篤之助：中央大学論文集14, 1 (1993).

（4）伏見康治：日経サイエンス，1993年 7 月号, p. 29.

(5) 朝日新聞，1992年 3 月 22 日.

(6) “ロシア連邦領土に隣接する海洋への放射性廃萧物 の投萧に関する事実と問題”，1993年 2 月（科技庁 仮訳版あり)。

(7) 野口邦和：日本科学者会議第19回原子力発電全国 シンポジウム予講集, 1993年 8 月, 福岡, p. 14 .

(8) ウラル・カザフ核被害調查団編：“大地の告発”, (1993), リベル夕出版.

(9) KapitzA, S. : Bull. At. Sci., 48 [4], 8 (1992).

\section{III-3. 原子炉の安全性の向上}

日本原子力研究所 鴻坂 厚夫

\section{はじめに}

旧ソ連設計の原子炉のうち，黒鉛減速軽水冷却 沸騰水型炉 RBMK の安全問題については, 千ェ ルノブイリ事故後の種々の調查を通して比較的よ く把握されているといえるが, 加圧水型軽水炉 WWER (IAEA では従来からよく用いられる呼称 VVER に替えてこの呼称を正式としている）について の情報は，最近まで西㑡専門家には極めて限られ ていた。そのような状況が一変して, 情報が急速 に増え，WWER型の原子炉の安全問題が大きく クローズアップし, 国際問題化したのは, 東西の 壁の崩壊が契機である。

1989年, ベルリンの壁崩壊後, 当時の西独原子 炬安全協会GRSによって東独にあるWWER の 安全評価が実施され, その結果から, 広く東欧等 で運転中の旧型の WWER-440/230の安全問題が 顕在化した。そして, 東欧諸国自らの要請に基づ
き，1990年IAEA はこの型の炉について，各国の 専門家による安全評価等の支援活動を開始した。 この活動はその後WWERのより新しい型式およ びRBMKにも拡大され，現在も続けられている。

IAEAによる安全評価や改善勧告の取りまとめ 等の技術的側面での支援活動ととあに, その結果 を踏まえて，東欧諸国およびCIS 諸国において， 改善が進められつつある。また, CEC, G-24等の 国際機関あるいは 2 国間協定の下で, 財政援助を 含む改善のための支援活動が展開されている。

筆者は最近, IAEAの活動のうち, WWERに 関する支援プログラムの運営委員会に参加してお り，会合に提出される報告書等加ら改善の様子を 知る機会を得ている。以下では WWER を中心 に，その概要を述べる。

\section{WWERの改善}

WWERには 3 世代ある。1970年代初頭に供用 開始したWWER-440/230(第 1 世代), 1980年代初 頭に供用開始したWWER-440/213(第 2 世代) お よび1980年代半ば以降に供用開始した WWER1000 (第 3 世代)である。当然のことながら，旧い 
世代のものほど多くの問題を抱えている。第 III- に各炉型の $\operatorname{ECCS}$ (非常用炬心冷却系) の主要パラ 1 表にWWERの運転状況を示す。また，世代ご メー夕を，第 III-3 表に格納システムの主要パラ との安全設計の相違の典型例として, 第 III-2 表 メータを示す。

第 III-1 表 WWERの運転状況

\begin{tabular}{|c|c|c|c|}
\hline & WWER-440-230 & WWER-440-213 & WWER-1000 \\
\hline チェコ & & ドコバニ 1〜4 & テメリン 1,2 (建) \\
\hline スロヴァク & ボフニチェ1,2 & $\begin{array}{l}\text { ボフニチェ } 3,4 \\
\text { モコヴィチ 1〜 4 (建) }\end{array}$ & \\
\hline ブルガリア & コズロドュイ 1 4 & & ベレネ 5,6 (建) \\
\hline ハンガリー & & パクシュ 1〜4 & \\
\hline ロシア & $\begin{array}{l}\text { ノボボロネズ } 3,4 \\
\text { コラ } 1,2\end{array}$ & コラ 3,4 & $\begin{array}{l}\text { ノボボロネズ } 5 \\
\text { カリニン } 1,2 ; 3,4 \text { (建) } \\
\text { バラコヴォ } 1 \sim 3 ; 4 \text { (建) }\end{array}$ \\
\hline ウクライナ & ロヴノ 1,2 & & $\begin{array}{l}\text { ロヴノ } 3 ４ \text { (建) } \\
\text { ザポロジェ 1〜 5； } 6 \text { (建) } \\
\text { 南ウクライナ 1〜3；４（建) } \\
\text { クメルニッキ 1；2４（建) }\end{array}$ \\
\hline アルx=ア & メザモ 1,2 & & \\
\hline
\end{tabular}

第 III-2表 WWERのECCS主要パラメータ(1)

\begin{tabular}{|c|c|c|c|}
\hline 項 目 & $\begin{array}{l}\text { WWER- } \\
440 / 230\end{array}$ & $\begin{array}{l}\text { WWER- } \\
440 / 213\end{array}$ & $\begin{array}{c}\text { WWER- } \\
1000\end{array}$ \\
\hline \multicolumn{4}{|l|}{ 高圧注入系 } \\
\hline 系統数 & 2 & 3 & 3 \\
\hline \multicolumn{4}{|l|}{ 注入ポンプ(容量/圧力） } \\
\hline$\left(\mathrm{m}^{3} / \mathrm{h} \cdot \mathrm{MPa}\right)$ & $50 / 12.5$ & $65 / 12.8$ & $160 / 10.8$ \\
\hline \multicolumn{4}{|l|}{ 低圧注入系 } \\
\hline 系統数 & & 3 & 3 \\
\hline \multicolumn{4}{|l|}{ 注入ポンプ(容量/俚力) } \\
\hline 蓄圧注入系 & なし & & \\
\hline 系統数 & & 4 & 4 \\
\hline \multicolumn{4}{|l|}{ 蓄圧タンク（容量/圧力） } \\
\hline$\left(\mathrm{m}^{3} / \mathrm{h} \cdot \mathrm{MPa}\right)$ & & $42 / 5.5$ & $50 / 6.0$ \\
\hline \multicolumn{4}{|l|}{ 格納システムプレイ系 } \\
\hline 系統数 & 1 & 3 & 3 \\
\hline \multicolumn{4}{|l|}{ 非常用給水系 } \\
\hline 系統数 & 2 & 3 & 3 \\
\hline $\begin{array}{l}\text { 格納システム内 } \\
\text { サンプ }\end{array}$ & あり & あり & あり \\
\hline
\end{tabular}

\section{(1) WWER-440/230(第 1 世代)}

WWER-440/230の設計思想は西側のそれと大 きく異なり，特に安全性の面では西側の水準とは 大分隔たりがあり，多くの欠点を有することか ら,この炬の安全性がいち早く国際問題となっ た。IAEA は, 西側専門家の協力を得て, 安全課 題の抽出および重要度分類等のまとめを行い,
第 III-3 表 WWERの格納システム主要パラメータ

\begin{tabular}{|c|c|c|c|c|}
\hline \multicolumn{2}{|c|}{ 項 目 } & $\begin{array}{r}\text { WWER- } \\
440 / 230\end{array}$ & $\begin{array}{l}\text { WWER- } \\
440 / 213\end{array}$ & $\begin{array}{c}\text { WWER- } \\
1000\end{array}$ \\
\hline 形 式 & & 密閐コシパー & 密䦓コンシバー & 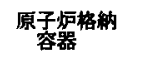 \\
\hline 構造材 & & 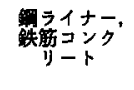 & 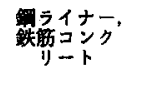 & 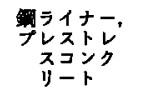 \\
\hline 設計圧力 & (MPa) & 0.1 & 0.1 & 0.56 \\
\hline 設計温度 & $\left({ }^{\circ} \mathrm{C}\right)$ & - & - & 150 \\
\hline 漏洩率 & (vol \%/d) & 600 & 0.2 & 0.1 \\
\hline 内容積 & $\left(\mathrm{m}^{3}\right)$ & 14,000 & - & 66,000 \\
\hline
\end{tabular}

1992年 2 月, 報告書 TECDOC-640 として刊行し た ${ }^{(2)}$ 。この報告書の内容は最近の「本誌」の資料 ${ }^{(3)}$ の中で詳しく紹介されている。以下でその概要 と, 主な安全課題についての改善状況を述べる。

(1) TECDOC-640

IAEA は1990年から約 2 年をかけて, 旧ソ連・ 東欧に存在するこの型の炉の発電所を対象に, 広 範な安全評価の作業を行い, 設計上·運転上の安 全課題を抽出し、ランキングを行なった。ランキ ングは安全に関する酳念の度合いに応じて 4 つの カテゴリーに分類された。第 III-4 表に安全課題 のランキングを示す。抽出された課題は, 設計関 連が60項目, 運転関連が47項目で, それぞれ,

I. 国際的慣行から逸脱

II . 深層防護が損なわれており，是正が必要 
第 III-4 表 WWER-440/230についての 安全課題のランキング(3)

\begin{tabular}{|c|c|c|c|c|}
\hline \multirow{2}{*}{ 分野 } & \multicolumn{4}{|c|}{ 分類(カテコリー) } \\
\hline & I & II & III & IV \\
\hline \multicolumn{5}{|l|}{ 設計 } \\
\hline 炬 心 & 0 & 4 & 0 & 0 \\
\hline システム & 0 & 5 & 7 & 3 \\
\hline コンポーネント & 0 & 2 & 5 & 5 \\
\hline 計装·制御 & 0 & 4 & 7 & 1 \\
\hline 電 気 & 0 & 1 & 2 & 2 \\
\hline 事故解析 & 0 & 4 & 5 & 0 \\
\hline 火災の防訬 & 0 & 0 & 3 & 0 \\
\hline （小 計） & $(0)$ & (20) & $(29)$ & (11) \\
\hline \multicolumn{5}{|l|}{ 発電所運用 } \\
\hline マネージメント & 2 & 3 & 6 & 2 \\
\hline 運転手順書 & 0 & 2 & 1 & 1 \\
\hline 発電所運転 & 1 & 2 & 3 & 0 \\
\hline 保 守 & 1 & 2 & 0 & 1 \\
\hline 訓 練 & 1 & 1 & 3 & 0 \\
\hline 緊急時計画 & 0 & 2 & 3 & 0 \\
\hline (小 計) & (5) & (12) & $(16)$ & (4) \\
\hline 合 計 & 5 & 32 & 45 & 15 \\
\hline
\end{tabular}

III. 深層防護の概念が不十分で, 直ちに矯正 措置が必要

IV . 深層防護の概念が受入れ難く，直ちに問 題解決のための対応をとるとともに，暫定 的な補足的対策の実施が必要

を意味している。緊急性が高いカテゴリーIIIが45

項目，IVが15項目と大きな割合を占めている。

(2) 主要な安全課題之改善状況

比較的対策が簡単な課題については，すでに多 くの国において対策が終わっているかあるいは実 施されつつあるが(補足的措置を含む)，この炉型の 根本的な欠陷のいくつかを克服するための改善に ついては, 対策案はあるものの, 資金と時間を要す るため未実施のものが多々ある。また，害施状況 は国によって異なり，全体としてブルガリア，スロ ヴァキアでは進んでいるが，ロシアでは遅れてい るようである。以下では, 計画中のあのあ含め, 安 全課題の主な項目とその改善策について述べる。

$a$. 圧力容器の炤射脆化

課題：炉心から容器壁までの距離が短く, 高い照射量を受ける構造。Cu, Pの含
有量が多い。監視試験片が挿入されて おらず脆化度の把握が不確実。

対策： 焼鈍をほとんどすべての炉で実施。 フラックス低減対策として炬心周辺領 域にダミ一燃料を配置。注入水の温度 を $55^{\circ} \mathrm{C}$ に上昇。今後，脆化度予測式の 開発等が必要。

b. 崩壊熱除去

課題： 崩䏅熱の除去は蒸気発生器 $(\mathrm{SG})$ を介 してのみ行われるが，そのための給水 系はすべてタービン建屋にあり，火災 等の共通要因で水供給培失の危険性が 高い。

対策： 非常用給水系および余熱除去 (RHR) 系それぞれの圥長性改善之物理的分 離。タービン建屋外に新たな大容量非 常用給水系を設置。

c. LOCA(冷却材喪失事故)時の炻心冷却

課題：1 次系配管には最大 $500 \mathrm{~mm}$ 口径ま であるが，低圧注入系および蓄圧注入 系がなく，ECCSは32 mm 口径までの 破断に対してのみ対応。2 系統しかな く，圥長性に欠け物理的分離が不十分 で，共通要因による機能喪失のリスク が大きい。

対策： $500 \mathrm{~mm}$ 配管に対しては，LBB(破断 前漏油)概念が適用できるとしてDBA (設計基準事故)の対象加ら除外し，2 番 目に太い $200 \mathrm{~mm}$ 配管の破断を DBA とし，これに対応可能なようにECCS を增強。几長性む改善。

$d$. 閉じ込め機能

課題： 格納容器はなく, 主要な 1 次系機器 を内部に収めた密閉型コンパートメン ト方式で，気密性が悪く，小容積のた め耐圧性が低い(過圧 1 気圧)。LOCA 時にスブレイ系が作動しない場合は， 段階的に外部へベントする方式。

対策： ハッチカバー, 扉, 貫通部等の気密性 を改善。 $200 \mathrm{~mm}$ 配管破断を DBA と し，閉じ込め機能を改善。 


\section{（3）今後の動向}

この型の炉は, 上述のように多くの欠点を有し ていることから，西側諸国内に長期にわたって動 かすべきでないとする意見がある一方，炉を運転 している国の多くが電力供給のかなりの割合をこ の炉に依存しており，今後とも利用せざるを得な い事情にあるため，国際議論は複雑である。技術 的には，この型の炬について大規模な改善が図ら れて，安全性が高まる方向に支援を継続すること になろう。

（2）WWER-440/213(第 2 世代)

WWER-440/213 は，原子炉の基本的構成が WWER-440/230 と同等であるが, 種々の改良が なされており，安全のレベルはWWER-440/230 に比べてかなり高められている。すなわち，

・ DBA として, 配管のうち最大口径であ る500 mm 配管の破断を想定。

- ECCS として, 蓄圧器 4 基, 高圧および 低圧注入系を 3 系統装備。

- 閉じ込め機能の改善として, 耐圧性の向 上, 事故時の圧力抑制のために，新たに大 規模なバブルコンデンサ建屋を付設。 などである。

しかし，多くの改善すべき点も指摘されてい る。この炉型に関しては，それを有する国の間で 情報交換が積極的に行われ，改善策について共通 のリストが作成されている。現在この改善策につ いて，IAEAによるレビューが行われているとこ ろであり，主なトピックスは，次の通りである。

- 圧力容器の使用条件の緩和

・1 1 次系圧力バウンダリーの保護

・ 過渡事象の管理能力の向上

- 火災対策

・アクシデントマネージメントの整備

なお,この炬型の最大の特徴であるバブルコン デンサ施設の性能は実験的に確認するべきである とされており, OECD/NEAにおいて,このトピッ クに焦点を当てた国際研究協力が検討されてい る。

（3）WWER-1000(第 3 世代)

この炉型は，基本的な安全設計の概念において 西側のPWR とほぼ同等であり, 高い安全のレベ
ルを実現している。その特徵は，

- 耐圧 4 気圧の鋼鉄内張りのコンクリート製 の格納容器を設置。

・DBA として最大口径 $850 \mathrm{~mm}$ 配管の破断を 想定。

- ECCSとして, 蓄圧器 4 基, 高圧および低 圧注入系を 3 系統装置。

などである。

しかし，より一首の安全性の向上を図る必要が あるとして, 種々の改善点が指摘されている。そ のうち, 特徴的な事項は, (1)横置き SGの健全性 および(2)炬心安定性の改善である。

前者は，この炉型の SGでこれまで多くの亀裂 が発生している問題である。最近この問題につい てIAEA 主催の専門家会議が開催され，原因の調 查分析が行われた。その報告の要点は, 次の通り である。

- 1986年から91年にかけて，19基運転中の原 子炉の76個の SGのうち，24個にクラックが 発生(兆候も含めればもっと多い)。

- 発生場所は 1 次側低温コレクタで, 伝熱管 接続部が V字型に分布している部分。

・クラックは最大で $1,000 \mathrm{~mm}_{\text {。 }}$

一原因は，爆着拡管による残留応力，および $280^{\circ} \mathrm{C}$ 付近で急激に延性が低下するコレクタ 材料の特性などによる環境促進型応力腐食割 れ。

これまで 6 基のSG が取り替えられた。今後の 対策として, 残留応力除去のために管孔内側から 熱処理を施すなどが提案されているが，さらに検 討を重ねることになっている。

炬心安定性の問題は計測制御に関することで, 出力制御方式が不十分で，Xe 振動が克服できな い場合があるとのことであり，安全課題ではない かもしれないが, ティピカルな問題と考えられて いる。

\section{RBMK の改善}

RBMK は，第 III-5 表に示すように，見在ロシ ア,ウクライナ,リトアニアにおいて全部で16基稼 働している。設計の観点から 3 つの世代に分か れ, 安全性も世代が進むにつれて向上している。 
第 III-5 表 RBMKの運転状況

\begin{tabular}{|c|c|c|c|}
\hline & 第 1 世代 & 第 2 世代 & 第 3 世代 \\
\hline \multirow[t]{2}{*}{ ウクライナ } & チェルノブイリ1 & チェルノブイリ 3 & \\
\hline & チェルノブイリ 2 (停) & & \\
\hline \multirow[t]{3}{*}{ ロシア } & クルスク 1,2 & クルスク 3,4 & クルスク 5 \\
\hline & レニングラード 1,2 & レニングラード 3,4 & \\
\hline & & スモレンスク 1,2 & スモレンスク 3 \\
\hline リトアニア & & イグナリナ 1, 2 & \\
\hline
\end{tabular}

IAEA はRBMKについてもその安全評価を実 施するなど，改善に向けて種っの支援を進めてい る。その活動は，WWERの場合と異なり，炝を 運転している国々自身がまとめた改善計画の内容 をレビューすることから始められた。その結果が 1993年 3 月, TECDOC-694(4) として刊行された。 以下にその概要を示す。

レビューは各国からの専門家を集め，すでに実 施済または実施中の対策および計画中の対策につ いて評価を行い，勧告を含めて取りまとめられ た。レビューの対象として取り上げられた分野 は，核計装・制御, 圧力バゥンダリーの健全性, 事 故緩和, 電源系である。それぞれについての主要 課題と実施済または実施中の改善策の概要は，以 下の通りである。

(1) 核計装·制御

$a$. ボイド反応度を 1 \$以下とする対策

- 80本の吸収棒を運転中炣内に㨉入

・燃料濃縮度を $2.0 \%$ から $2.4 \%$ に増加

. 反応度操作余裕を増加, 等

$b$. 原子炉停止機能の改善

・制御棒下部の軽水領域の除去(ポジティ ブスクラムの排除)

・制御棒挿入時間の短縮 $(19 \mathrm{~s}$ ⿸12 $\mathrm{s}$ に)

・ $2.5 \mathrm{~s}$ で挿入できる急速停止棒の設置, 等

（2）圧力バウンダリーの健全性

$a$. 圧力管の健全性確保

- 圧力管入口流量制御弁の構造変更·更新

－圧力管の交換(黒鲐フロックとの接触防止)

- 漏洩検出装置の追加, 等

$b$. 圧力バウンダリーのISI（供用期間中検查） 強化

(3) 事故緩和

$a . \operatorname{ECCS} の$ 信頼性向上
・分配ヘッダーへの逆止弁の設置(第 1 世 代)

- ECCS ポンプの増設による多重化(第 1 世代), 等

- 事故時局所化設備の強化と圧力抑制系 の増設

(4) 電源系の改善

$a$. 非常用電源の信頼性向上(多重化, 系統分離) 上記に加え，多くの改善策む計画中である。

現在IAEA は，以上の改善策に対する安全評価 を行い, 改めて安全課題の整理招よび重要度分類 を行なっている。

おわりに

東西の壁が崩壊したことによって，少し前まで はほとんどわからなかった東側の原子力事情が， 我々にあ見えてくるようになった。改めて，技術 交流の途絶がいかに大きな技術格差を生み出すか を痛感させられる。また原子力の場合，その格差 が我々自身の技術の将来に影を落としかねないと 心配させられる。その意味でも，旧ソ連設計の原 子炉の安全性について関心を持たざるを得ない。 幸い，壁の崩壊で国際機関としてのIAEAの果た し得る役割が増している。今後ともIAEAの場を 通して,我が国として寄与して行く必要があろう。

\section{一考文献—}

（1）“旧ソ連型炬データブック（資料編）＂（1993），原 安協.

(2) Ranking of safety issues for WWER-440 model 230 nuclear power plants, IAEA-TECDOC-640, (1992).

（3）森谷 㴊：原子力誌，35[10]，905 (1993).

(4) Safety assessment of proposed improvements to RBMK nuclear power plants, IAEA-TECDOC694, (1993). 


\section{III-4.旧ソ連, 東欧への原子力安全支援}

$$
\begin{aligned}
& \exists ー ロ ッ \text { パ共同体委員会(CEC) } \\
& \text { G24 原子力安全支嗳調整センター } \\
& \text { IAEA シニアリエソンオフィサー }
\end{aligned}
$$

下村和生

\section{1. 概 要}

ベルリンの壁崩壊に象徴された東西冷戦の終結 捛よびソ連邦自体の解体は，旧ソ連邦の影響のも とで共産主義体制をとっていた国家群，いわゆる 東側諸国に対して急速な政治的変革をもたらすと とあに，社会的および経済的な混乱を招いた。こ の変革による情報公開等に伴い，これらの国々の 原子力発電所が, 安全性に重大な問題を持ったま ま運転されていることが，IAEA 等の安全評価に よりその実態が明らかにされた。

これらの原子力発電所の安全問題および支援計 画は，一連の主要先進 7 力国経済サミット (G7サ ミット)で検討され，支援のための行動計画が策 定された。行動計画の推進のために, 先進24力国 (G24)による調整メカニズムが強化され，支援プ ロジェクトの計画・実施に関する調整が開始され ている。また，支援のための多国間資金として， 欧洲復興開発銀行(EBRD)に原子力安全基金も設 立された。すなわち，旧ソ連，東欧諸国への原子 力安全支援の当面の国際的枠組み作りは終わり, 実施段階に入った(第 III-1 図)。

\section{2. 原子力発電の現状と安全問題}

旧ソ連では，黒鉛減速軽水冷却炉(RBMK)が15 基, 旧ソ連製加圧水型軽水炣(WWER)24基などが 運転中であり，電力供給の約10\%を占める。特に リトアニアは，運転中の RBMK 2 基で電力設備 容量の約 $50 \%$ を占め, 発電電力量では約 $80 \%$ 占 めている。ブルガリア,ハンガリー, チェコ, スロ バキアにおいてむ，原子力発電の電力供給に占め る割合が30〜 50\% と高く，すべて旧ン連製の WWERである。

RBMKについては，1986年に発生したチェル ノブイリ 4 号機の事故により世界を震憾させたこ とで知られているが，その後の対策状況にっいて は閉ざされた旧ソ連体制下では実態が把握され
ずなお重大な愍念があるすのと認識されてき た。これに加えて, 旧ソ連から東欧諸国に輸出さ れ運転されているWWERについても，第 1 世代 の440/230型は格納容器がない, 緊急炉心冷却設 備が不十分など, RBMK 同様, 重大な安全問題 があることが，IAEAなどの評価で明らかとなっ た。IAEA は，特別拠出安全評価プロジェクト (加盟各国加ら任意に扰出される特別予算)の中で, RBMK とWWER の両炉型について, 改善すべ き安全問題の摘出,重要度評価等を引き続き実施 している。これらの活動は, その迅速性と専門性 が国際的に高く評価され，この問題に関する安全 評価活動の中核を担っている。我が国む，この IAEA のプロジェクトに対して, 資金の拠出, 専 門家の出向等により積極的に貢献している。

\section{3. 国際的支援の枠組みの形成}

旧ソ連, 東欧の原子力安全問題は一連の G 7 サ ミットにおいて主体的に取り上げられるに至っ た。1991年のロンドンサミットにおいて，東欧お よびソ連における原子力発電所の安全問題は, 先 進国が取り組むべき緊急の国際問題として取り上 げられ，翌92年の G7 7 ニヘンサミットにおい て，G7諸国は支援を多国間の行動計画の枠組み の中で提供することを約束した。この行動計画 は, ミュンヘンサミットに先立ち G7 原子力安全 ワーキンググループにて策定され，運転中の RBMK (15基)および WWER-440/230(10基)を重 大な安全上の酳念がある原子炉として可能な限り 早期に停止されるべきとするとともに，短期的技 術改善, 運転上の安全性向上および規制制度の強 化に関して支援すべき項目を盛り込んだ。

また，中·長期的な対策については，旧ソ連，東 欧諸国の中・長期的なエネルギー需給を展望した 原子力の位置づけの中で検討すべきとして，世界 銀行, IEA(国際エネルギー機関), EBRDに調查を委 託した。その報告書は先の東京サミットに報告さ れ，次回のナポリサミットに向けて検討が開始さ れている。また，2国間支援プロジェクトを補完 する多国間の支援基金が1993年春，原子力安全基 金としてEBRDに設立された。我が国もこの基 金に, 向こう 3 年間で総額1, 200万米ドルを拪出 


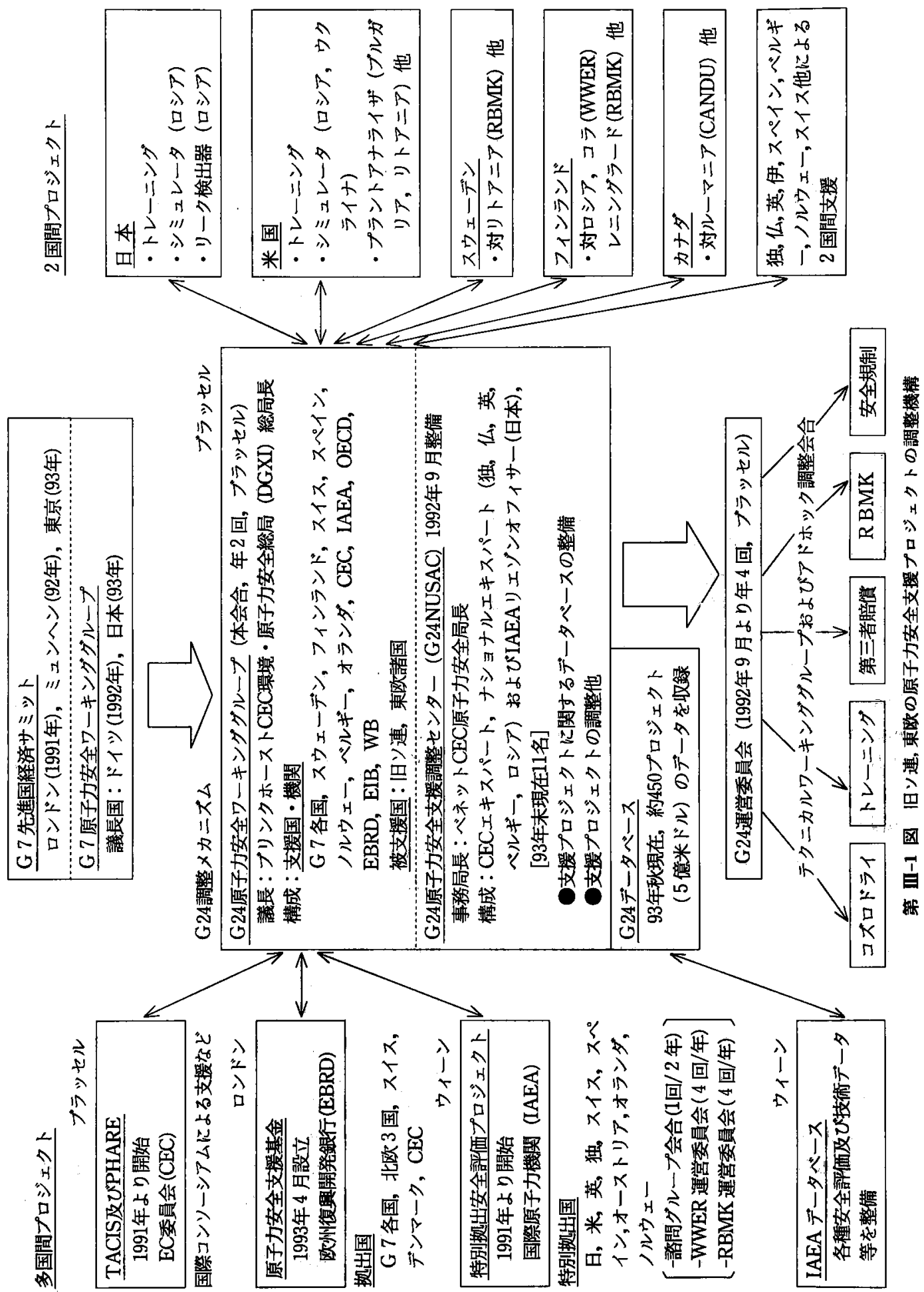


することとしている。

\section{G24原子力安全支援調整メカニズム}

G7は，合意された行動計画を効率的に実行さ せるため, 1989年のG7アルシュサミットにて形 成されたG24による東欧支援調整メカニズムを拡 張·強化し, 旧ソ連, 東欧諸国の原子力安全の支援 調整を行わせるための専従の事務局をもつG24原 子力安全ワーキンググループを設立させた(92年 9 月)。この事務局は，ブラッセルに本部を置く ヨーロッパ共同体委員会(CEC)に，G24原子力安 全支援調整センターとして設立され，CECの専 従スタッフ5名に加え，93年より5名のナショナ ルエキスパート(仏，英，独，ロシア，ベルギー) と IAEAからのシニアリエソンオフィサー(筆者)が 加わり合計11名の体制となっている。G24調整メ カニズムは，IAEAをテクニカルアドバイザーと して，2 国間およびEBRDの原子力安全基金等の 多国間支援プロジェクトの総合調整センターとし て機能する任務を担っている。

G24調整メカニズムのもうひとつの重要な任務 は支援プロジェクトのデータベースの整備であ る。G24のデータベースには，93年秋の時点で 2 国間および多国間のプロジェクト, 総額約 5 億米 ドル,約450のプロジェクトが収録されている。こ のデータベースには，我が国の支援プロジェクト として, IAEA の特別拠出安全評価プロジェクト
への人的および資金的貢献, 原子力安全に関する 国際研修プログラム, ロシアに対する運転訓練の ためのシミュレータの設置, およびマイクロフォ ンによる異常検出システムの技術協力もこの中に 含まれている。

\section{5. 今後の展望}

旧ソ連, 東欧の原子力安全支援に関する国際的 な枠組みは, 問題が提起されてから 2 年余という 異例とあいえる速さで整備され，実行に移されつ つある。ところが支援国は，これらの諸国が当

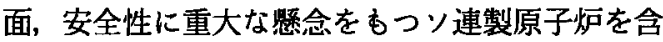
む原子力発電所への依存なくして, エネルギー問 題を解決できないことを認識し，そのジレンマに 苦悩している。また，これらの支援が実を結ぶか 否かは, 原子力発電所を保有する当該国に委㕲ら れている。すなわち，絽り返しいわれることであ るが，セーフティカルチャ一の酮成がなされ，自 助努力により自立することである。

しかしながら幸いにも，近年のこれらの国々の 原子力安全に対する取組みは注目すべきものがあ るし，自力による改善あ着実になされている。一 方では，支援プロジェクトを通じて，支援側・被 支援側の両者に携わる人々の信頼関係の構築之相 互の忍耐強い対話により, 改善は確実に一歩ずつ 進展している。

否かは各極の意向を得て決定することとしてい る。作業は, 現在第 2 段階である工学設計活動 (EDA)に入って, 1 年余りの時期に当っている。

EDA は1992年 7 月から 6 年にわたるむのであ る。その内容は, 我が国の呼び名に従えば, 詳細 設計に相当する設計作業と工学 R \& D から成り 立っており，その実施により ITER 建設に関する 決定を行う上に必要な技術資料を整備することを 目的としている。 れ

核融合開発は，資源として豊かであり，安全性 や環境保全性の高いエネルギー源の開発を目指す ものである。推進に当っては，炤心プラズマに関 する科学的な研究とともに先端技術の開発が必要 


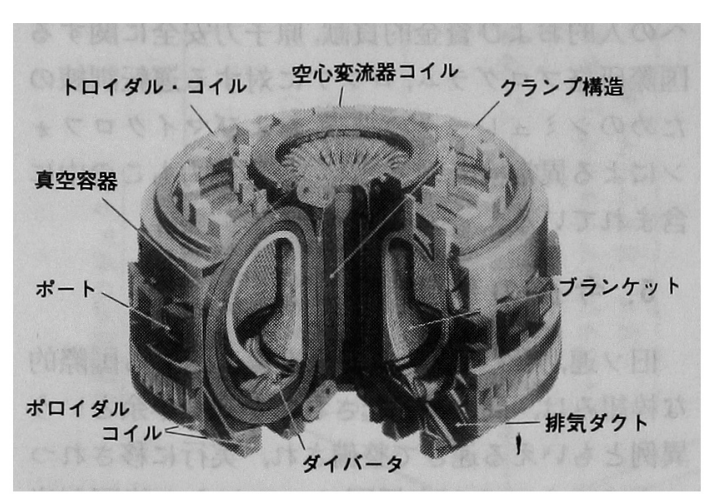

写真 IV-1 ITER鳥瞰図(クライオスタットを除く)

であり，長期にわたる期間と多額な資金をかけ， 計画的に進める必要がある。それだけに国際協力 による資金の有効利用やリスクの低減を目指し， すでに10数年にわたる日米核融合協力を初め, 密 接な国際協力を進めてきた。

一方，開発が害用化や製品化に近づくとき，そ の所産には産業財産としての価值意識が高まり， 通常の国際協力にはなじみ難くなるという一面が ある。しかし, 実験炉の段階ではなお長期にわた る開発を続ける必要があることなどから, ITER を国際協力によって建設しょうという構想に国際 的合意が酾成されてきたのである。

以下，EDAを中心として ITER 計画について 紹介する。そ机に当っては, 枠組や技術的詳細に ついては文献 ${ }^{(1)} に$ 譲り, 国際協力としての側面か ら説明することとしたい。

\section{1. 大型科学技術亡国際協力}

大型の科学技術開発計画, いわゆるビッグサイ エンスにおける国際協力への適合性については, 多くの論者によって議論がされてきた ${ }^{(2)}$ 。一般 に, 計画に次のような特徴がある場合, 国際協力 としての適合性が高まると考えられる(3)。

(1) 大型の設備, 多大な経費, 多くの人的投資 が必要である。

（2）環境問題のように, 1 国では対応が困難 で, 先進国の国際協力が不可欠である。

(3) 人類共通の知的財産として未来に対する 新たな可能性を開拓すると期待されるなど。 ITER計画には，上に述べた特徴がかなり高い
レベルで具わっていることが理解頂けよう。ここ にITER 計画が，関係者の熱意のみならず政策立 案者の注目と支持を集めてきた理由の一つがあ る。

国際協力が成功する要件についても，これまで 分析・検討が行われてきた (2)。すなわち，

(1) 第 1 に重要なことは, 開発計画そのあの が優れていることである。これは，国際協 力に不可欠な条件である参加極の安定した 支持を確保するための要件であある。

(2) 第 2 に重要なことは，参加国の受ける利 益(精しくは、コスト/ベネフィット比)がバラ ンスすることである。これによって国際協 力の同様に不可欠な条件である参加極の間 の公平感や満足感を確保することができ る。

(3) 第 3 に重要なことは, 参加極や個人の間 の信頼感と高度の理解を醸成することであ る。社会的慣習や文化的背景の隔たりが円 滑な国際協力の障害となる場合がしばしば ある。この意味で, 長期にわたる協力の寒 践とこれによる理解と信頼の育成の重要性 は極めて高い。

これに関係し，しばしば指摘されている ように, 協力構想の初期の段階加ら研究者 間の意見交換を行い，適切な時期から政策 立案者の間の討議を開始することにより， 参加極間の協調を図ることが大切である。

（4）最後に重要と思われることは国内基盤の 育成である。それは, 国内における研究活 動による新鮮な発想や若手研究者の育成に より，国際協力に起因する単一化を克服す るためにも，将来の産業化の基礎となる産 業インフラや技術基盤を確立するためにも 必要である。

ITER計画は，上に述べた要件をすべて理想的 に具えているわけではない。しかしながら，過去 長期間にわたる核融合協力の中から実験炬に関す る協力が練り上げられ，それが1990年11月のレー ガン・ゴルバチョフ首脳会談を契機として政策レ ベルの協議へ高められたことは事実である。 


\section{ITER EDA計画とその現況}

ITER EDAの推進においては, ITER 理事会が その最高意志決定機関としての役割を担う。これ を補佐する機関として，技術諮問委員会(TAC) と 運営諮問委員会 (MAC)があり, 特定の課題につ いて時限を定めて作業を行う特別作業グループ (SWG)が設立される。設計作業の中核は, 所長 と共同中央チーム(JCT)であり, JCT は, サン ディエゴ(米), 茨城県那珂町(日),ガルヒン (EC, 独) の 3 サイトに駐在する。JCTは, 参加 4 極加ら 派遣されるメンバーから成る混成チームである。 各極にはホームチーム(HT)が設置され, 所長と の間に調印される作業取極めに従って工学R \& D と個々の設計作業を実施する。

これまでのEDAにおける主要な活動には次の ようなあのがある。

（1）ITERの詳細技術目標の決定

ITER の「計画目標」は，自己点火と長時間燃 㜔、炬工学の総合試験などであり，EDA協定に記 載されている。しかし，これを設計作業に具体化 するに当っては，その前に「詳細技術目標」を詳細 に定める必要があった。このため理事会は SWG-1 を組織し, 直ちに原案の作成に当らせ た。審議は, 各極が実験炬の具体的目標としてい たものが必ずしも同じでなかったため容易ではな かった。しかし，精力的な国際作業によって3カ 月間で調整を完了し，理事会において承認され た。

\section{（2）ITERのアゥトライン設計の実施}

JCT は, 上記の詳細技術目標に基づいて設計 作業を開始した。それに当っては，炉本体の基本 構成, 主要構造, 主要諸元などを要求されるプラズ マ性能から適切な設計余裕を含めて定めることが 必要である。具体的に設計上のキーポイントに
なったのは, 装置寸法, 構造材・冷却材, コイル構 造などの選定であった。これに当っては，TAC が技術レビューに重要な助言を行い，これに沿っ た形で, 設計の概要(アウトライン)について 4 極 間の合意が得られるに至っている。

\section{(3) ITER 工学R \& Dの実施}

工学 R \& Dの開始に当っては,クリティカルパ スとなる大型の試験設備の分担関係の合意に達す ることが特に緊急を要した。特に, 超伝導コイル の試験設備については, 各極と JCT の間の精力 的な協議によって早期に合意に達することができ た。設計の詳細に依存性の少ない超伝導素材の製 作の分担について合意に達しており, 設計の進行 をにらみながら，素線加工，巻線加工などにおけ る分担についても順調に協議が進んでいる。

\section{むすびに}

核融合開発は，人類究極のエネルギーの塞現と いう長期的目標を持つあのであり，この意味で先 進国間の国際協力にふさわしい計画といえよう。 現在核融合分野における最大の国際協力計画であ るITER EDA 計画は，世界の先進 4 極の間の平 等な負担と受益を原則する先導的な国際共同事業 である。国際協力を成功に導く要件之対照すると き，EDA計画は惠まれた要素を具えてはいるす のの, 一層の改善に努めなけ扎ばならない。核融 合開発のためのみならず，世界に先例のない国際 協力の試みとして関係者の一層の努力が望まれる ゆえんである。

（1）例えば，エネルギー(特集号)，25[11]，(1992)，

(2) 例えは，鳥井弘之：国際問題 No. 388，17(1992); 吉川允二 : 同 上, 32 (1992).

(3) 1992年 3 月 OECD科学技術大臣会合における科学 技術庁平野科学審議官の発言. 


\section{IV-2．プルトニウムの民生利用}

東京大学工学部 鈴 木 篤之

はじめに

U 資源のエネルギー利用方法としては，U自身 の核分裂ばかりでなく，UをPuに変換しそのPu の核分裂を利用することが鍵を握っていることは よく知られている。

このPu利用を図る上で最も効率的な方途はい うまでもなく高速炉を用いる方法であり，原子力 の平和利用が構想された当初から, 高速炉の開発 が究極の目標とされてきた。事実, 米国で最初に つくられた実験灯は高速炬クレメンタインであっ た。それから約半世紀を経た今日, 高速灯の本格的 実用化にはなお至っていない。筆者には，高速炬 開発の道程,ひいてはPu利用の帰䞤は今まさに その分岐点に差し卦かっているように思われる。

\section{Puを取り巻く国際情勢}

現在の軽水炉型の原子力発電所においても，生 産されているエネルギーの約 $30 \%$ は Puの核分裂 によっている(1)。例えば，OECD加盟国では，電 気エネルギーの約 $30 \%$ が原子力であるから，Puに よる電気が $10 \%$ 程度を占めている勘定になる。し たがって，Puは現在であ立派なエネルギー源と なって貢献している。

しかし，U資源の利用効率は極めて低い。実際 にエネルギーに変換されているUは，Puの寄与

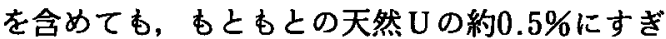
ない。これほど低くとす，例えば石油と比較した 場合，エネルギー生産性(質量当り)はなお約 10,000 倍であり，一方，価格は約 1,000 倍である

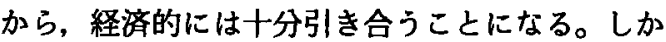
も，石油価格に連動して天然Uの価格は低位安 定的である。短期あるいは中期的な資源経済論か らみて，Puのリサイクル利用に対するインセン ティブは小さい。

諸外国の多くが再処理リサイクルを行なってい ない最大の理由はこの資源経済的観点にある。さ らに，再処理工場や高速炬の建設には長期の時間 と多額の投資を要するため, 深刻な財政難に宿っ
ている国々では，リサイクル利用がますます難し くなっている。米国が10数年前に民生用再処理を 断念したのは，カーター政権の核不拡散政策のた めであるこいわれることが多いが，より根源的に は，財政的および資源経済的観点からの判断の結 果であった ${ }^{(2)}$ 。

他方，米国と旧ソ連の間で冷戦構造が崩壊し， 核軍縮が急転回をみせている。戦略核を含む核兵 器の解体が検討されるに至り，搭載されている高 濃縮 U や高純度核分裂性 $\mathrm{Pu}$ が問題になり，その 取扱いを巡って国際的な議論が盛んになってい る。この点が $\mathrm{Pu}$ の平和利用のあり方や進め方に 改めて問題を投げかけている。

そのような混迷的様相の中で, 各国がそれぞれ に，研究開発の途を模索している。米国のクリン トン政権は財政の赤字の解消を最優先に大幅な予 算削減を図っており，ANLのIFR計画について あ放棄する方向が打ち出されているが，一方，解 体核兵器加らの Puに関しては, MOX 燃料とし て燃焼する案む，有力な選択肢として検討され始 められている。

フランスにおいてす，スーパーフェニックスの 運転再開に向けて公聴会が開かれ，運転免許の更 新を可とする報告書が県知事に提出された。安全 当局加ら安全再評価によって指摘された $\mathrm{Na}$ 火 災対策を講ずることなどを条件に，運転の再開を 可とする勧告が出されている。

\section{2. 日本のPu利用計画}

一方，日本では，英仏へ委託している再処理か ら回収されたPuの返還や「あんじゅ」の臨界を真 近にひかえ，国としてのPu利用計画を国の内外 に明らかにする必要性から, 原子力委員会が, 1991年 8 月に今後約20年間の計面の見通しを発表 している(3)。

それによれば，核分裂性 Pu 量に換算して, 2010年頃までの 20年間の需要累計は80〜90 $\mathrm{t}$, 供 給は約 $85 \mathrm{t}$ となっている。年平均に換算する之約 $4 \mathrm{t}$ 程度ということになる。この数字は，国の内 外で論議を呼んだ(4)。たまたま，ロシアが解体核 兵器からの約 $100 \mathrm{t}$ といわれる高純度 $\mathrm{Pu}$ を民生用 に放出してもよいと言い出したことから，日本の 
$85 \mathrm{t}$ という供給力は核大国, ロシア並みと少なく とも一部の人たちに受け取られた。

また，需要の $50 \%$ 以上が軽水炬へのリサイクル 利用になっていることあ問題であると指摘する人 あいた。軽水炉へのリサイクル利用は本来の利用 方法でなく過渡的なものであり，それが需要の大 勢を占めているということは計画に無理があるか らであるという指摘である。

国内の民間再処理工場が定常運転に入る2005年 頃を想定すると，軽水炉用燃料需要は全国で年間 $1,000 \mathrm{t}$ を超えているものと見込まれる。仮に， 年間約 $4 \mathrm{t}$ の核分裂性Puの全量を軽水炉リサイク ル用の MOX 燃料としても100 $\mathrm{t}$ 末満であるから， 総需要に対しては10\%以下ということになる。ま た, MOX 燃料加工事業を産業化するためには最 低 $100 \mathrm{t} /$ 年程度の規模が必要とされており，原子 力委員会の需給計画はこれらの点から適切な範囲 にあるあのと考えられる。

\section{3. 今後の課題}

$\mathrm{Pu}$ 利用を巡っては，今後とも国際的に論議さ れるであろう。日本の計画の構想を進めて行くに 当っては, 以下の点に留意する必要があると思う。

\section{(1) 経済性}

民生用と軍事用の最も大きな差異の 1 つは経済 的感覚にある。過去において軍事用再処理工場で 樑刻な事故が起きた最む大きな理由は安全思想の 欠落にあった。軍事用工場においては, 手段より あ目的が優先され，民生部門では不可欠な安全性 への配虑はほとんど無視されている。これと同じ ような意味で, 経済性への配虑む欠如している。

$\mathrm{Pu}$ の民生利用が今後定着化していくための第 1 の条件は，その経済性にある。実用化までのプ ロセスにおいては，もとよりある程度のコスト高 はやむをえない。しかし実用化に向けては，その コスト低減が図られるような確固たる技術的構想 をもっている必要がある。特に過去の軍事部門に おける苦い経験を超えて，安全性と経済性をいか にバランスさせるかが重要な課題になっている。

\section{（2）連秸性}

技術開発は地道な努力の不断の積み重ねに支元 られている。そのような努力を可能にする条件の
一つは技術開発の連続性にある。実際，安全性や 経済性に関わる技術進歩はそのような連続的技術 開発の成果に基づいている部分が少なくない。

例えば，MOX燃料加工技術を例にとると,「ふ げん」燃料から「あんじゅ」燃料への移転は, 結果 的には不連続的であった。軽水炬リサイクルの意 義はこの点の連続性にもあることを想起すべきで あるように思う。

\section{(3) 創造 性}

連続性だけでは，本当の意味での技術進歩を産 み難いことも事実である。原子力開発のこれまで の基本は，実験段階加ら原型段階之進み，さらに 実証段階を経て実用段階に至るというものであっ た。これは国の経済規模や産業規模, したがって エネルギー需要が右上がりの時代においてはごく 自然の発想であったが，今後予想される経済成長 や需要予測の下では, 新しい発想を必要としてい $る^{(5)}$ 。

高速炉開発が，国によって事情は異なるもの の，それぞれの開発段階において苦境に立たされ ているという事実が何よりもこの新しい発想の必 要性を如実に示している。日本において今後の計

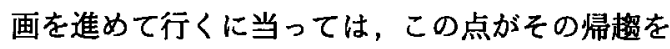
握っているように思われる。

\section{4. 公開性}

$\mathrm{Pu}$ の民生利用に対する彩念の一つに，情報が 公開されなくなり，一種の管理社会になるのでは ないかということが挙げられている。「あかつき 丸」の場合も, 最も強く求められたことは情報の 公開性であった。原子力委員会が Puの需給見通 しを発表したことはこの点を意識したためと思わ れるが，なお一層の公開性が必要であった。日本 政府は結果的に当初の頑固な姿勢を改め, 相当量 の情報を公開したが，後手に廻ったとの印象を拭 えなかった。

いわゆる安全性にはSafety と Security とがあ る。Securityに関する情報は非公開が原則であ るのに対し，Safetyに関する情報は公開が原則 である。Securityに関する情報をできるだけ局 限し, 後者の原則の観点から情報はできるだけ公 開することが望ましい。 


\section{5. 国際性}

$\mathrm{Pu}$ 利用には核拡散問題が付随する。日本が利 用計画を進めれば他国での核保有欲を刺激するこ とにならないか, あるいは日本の核保有への距離 を短くするのではないかという危惧が, 諸外国に はあることは紛れるない事実である。このような 不安には誠実に対応していくほかはない。

民生部門と軍事部門を明確に区別すると同時 に，日本の計画の透明性を高める観点から，国際 的な新しい制度を日本政府が提案しつつおること は, この点加ら国際的に高く評価されている。加 えて, 中国や朝鮮半島など原子力発電が拡大しつ
つある東アジアにおいて，原子力利用のあり方に ついて新しい枠組みを考えて行く時機にあるとも いえよう。

\section{—參考文献一}

（4）鈴木篤之: “原子力の燃料サイクル”，(1985), 電力 新報社。

(5) 同 上: $\mathrm{Pu}$ 利用の規模とテンポに柔軟性を, エネル ギーフォーラム, 337, 50 (1983).

(6) 原子力委員会 $「$ 核燃料リサイクル専門部会報告書」, (1991).

（7）鈴木篤之:原子力の新しい展開を図る，エネルギー フォーラム, 452, 34 (1992).

(8) Suzuki, A. : Japanese Nuclear Policy in a Changing World, 18th Uranium Inst. Annu. Symp. London, Sep. 1993.

\section{IV-3．発展途上国との技術協力}

（社）日本原子力産業会議 高橋 誠一郎

\section{1. 種々のレベルでの留学生, 研修生, 技術者の派遣}

原子力分野における我が国の発展途上国との協 力は，人材養成の面加見ると，主として近隣了 ジア諸国を対象として，大学，研究機関を中心に 研修生, 研究員の受入れが行われている。大学で 受け入れている学生は，文部省が奖励金を提供す る留学生制度，および東京大学,東京工業大学の 原子力特別コースのほか, 途上国政府の貫用で派 遣される学生, それに自費留学生があり, 学力の 向上を図るとともに, 最終的には学位を取得して 州国している。

このなかで，特に注目されるのはインドネシア の政府派遣留学生である。インドネシア政府は, 将来のインドネシアを科学技術立国にするための 基盤作りとして，海外経済協力基金加らの資金を あとに，インドネシアの科学技術系研究所が採用 した有能な職員を年間百数十人の単位で日本に派 遣している。その中で, 原子力庁の職員は現在約 100名である。したがって, 日本国内の原子力学 科のある大学にはほとんどインドネシアの留学生 が配置されている。
次に多いのは，中国, 韓国, 台湾となっている。 日本語の修得が他の外国人に比べ，比較的容易で あることと，文化，習慣が似ていることがこれら の地域の留学生数が多い理由である。

一方, 研究機関レベルでの研究員の受入れは, 原子力分野では主として科学技術庁の研究交流制 度が定着しており，日本原子力研究所, 動力炬・核 燃料開発事業団, 放射線医学総合研究所, 日本分析 センター,電子技術総合研究所等で年間約 70 名程 度 1 力月〜 1 力年の期間で受け入れている。（第 IV-1 図参照)

国際協力事業団息開発途上国の技術者や行政官 を対象として，研修員として我が国に受け入れ， それぞれの分野の専門的知識·技術の移転を行う ことを目的として研修事業を行なっている。なか でも毎年定期的に実施する集団研修コースは，各 国から1名ずつ10名程度で数力月間実施するもの で，300以上のコースがある。原子力分野では， 「原子力発電」(海外電力調查会), 「原子力基礎実験」 (原研)，「放射線安全管理実務者」(動然事業団)およ び「原子力安全規制行政セミナー」(原産)のコース がある。(括弧内は実施機関)

原子力発電分野の協力では, 海外電力調査会が 日本国内の電力会社の空口となり，中国, 台湾, 1 ンドネシアなど，原子力発電所をすでに運転して いるか，近い将来導入を計画している国を対象に 人材交流を実施している。 


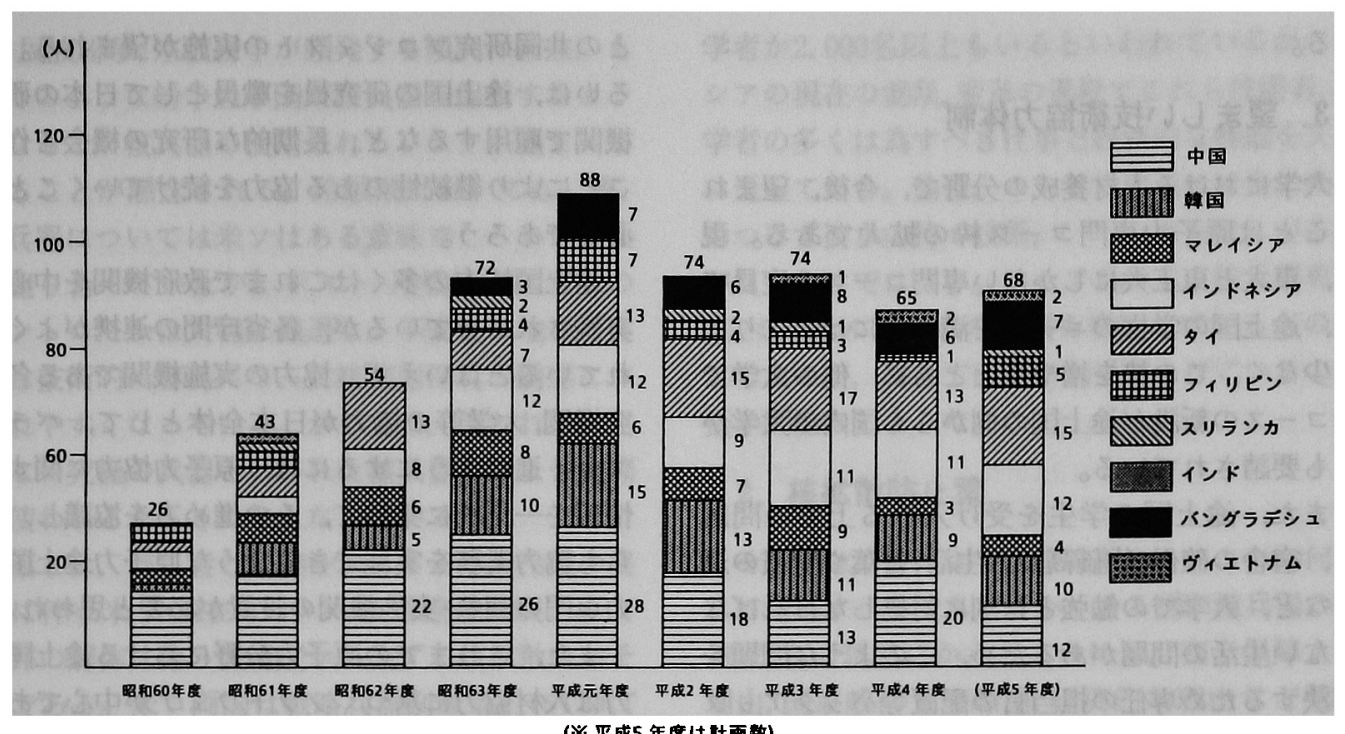

第 IV-1 図 原子力研究交流制度受入実績の推移表(国別)

我が国からの専門家の派遣については，やはり 科学技術庁の研究交流制度により各研究機関加ら 専門家が派遣されている。また，原研はインドネ シア, マレーシア,タイ,メキシコの原子力研究機 関との間で研究協力取決めを締結しており，それ に基づき毎年専門家を派遗している。

これらの人材交流の成果をさらに効果あるもの としていくには, 各途上国の研究機関での施設の 充実, 研究員の育成のための予算を確保する努力 を行うのはもちろんのことだが，日本の研究機関 でむ途上国の研究機関との共同研究プロジェクト を実施していくことなどにより途上国の研究員の 技術レベルの向上に努める必要がある。

\section{2. 原子力分野におけるアジアの地域協力}

$\mathrm{RI} \cdot$ 放射線利用分野における開発途上国への協 力は，大きく分けてIAEAが実施するものと，我

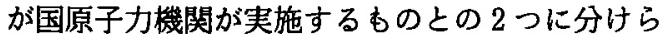
れる。

前者は, IAEAのアジア地域原子力協力協定 (RCA)に基づく多国間協力が主な活動であり，加 盟国はアジア,太平洋および極東地域の14 力国で あり, 1972年より始動している。RCA プロジェク 卜の協力分野は, RI·放射線の工業利用, 医学利 用，農業利用，放射線防護などであり，セミナー，
トレーニングコース, 専門家派遣等の方法により 協力を実施している。この RCA プロジェクトに は日本政府む特別拠出金を提供しているほか, IAEAの毎年の計画に沿って，日本の研究機関お よび大学の尃門家等も実施面で自主的に協力して いる。

後者は，我が国の原子力委員会が，1990年から 近隣アジア諸国を対象に毎年開催している「アジ 了地域原子力協力国際会議」のもとでのアジア地 域原子力協力である。この会議は近隣アジアの 7 力国との地域協力の具体化のための意見交換・情 報交換を行い，地域協力の活動についてコンセン サスを得ることを目的に開催されている。同会議 のあ之で，科学技術庁の主導に上り，RI·放射線 の農業利用, RI-放射線の医学利用, 研究炉利用, パブリック・アクセプタンスの 4 テーマについて, セミナー,ワークショップ, 現地調查等の具体的な 協力活動が開始されている。

課題としては，RCA プロジェクトについては, これに参加しているインド,パキスタンが核不拡 散条約未加盟国のため，日本としては研究炉およ び原子力発電技術分野にまで協力を拡大すること が難しいことである。原子力委員会主導のアジア 地域協力では， 7 力国以外のアジア各国，あるい は台湾などとの協力をどのように進めていくかで 
ある。

\section{3. 望ましい技術協力体制}

大学における人材養成の分野で，今後，望まれ ることは原子力専門コース枠の拡大である。現 在, 東大と東工大にしかない専門コースの定員で は, 途上国の学生のニーズを満たすにはあまりに あ少なく，この枠を増やすとともに，他の大学で のコースの新設が途上国の側からあ国内の大学か らも要請されている。

また，途上国の学生を受け入れる上での問題 は, 宿舎の確保, 物価高での生活,言葉や習慣の違 いなど，大学での勉強とは別に対処しなければな らない生活の問題があるため,このような問題を 解決するため専任の担当官の配置等バックアップ 体制を確立する必要がある。

研究機関において実施されている研究員の受入 れ，専門家の派遣の協力については，これまでに かなりの成果が上がっているように思われる。し かし, 日本の研究機関での実験・研究により, 途 上国の研究員が新しい技術を身につけて州国して あ研究予算, 実験施設, スタッフの体制等様々な問 題で，日本にいた時と同じような研究を継続する ことが困難な場合が多い。これらの問題の解決を 図るとともに，途上国の原子力技術レベルの向上 をさらに図るには，長期滞在の研究員による日本
との共同研究プロジェクトの実施が望まれる。あ るいは, 途上国の研究員を職員として日本の研究 機関で雇用するなど，長期的な研究の機会を作る ことにより継続性のある協力を続けていくことが 必要であろう。

途上国協力の多くはこれまで政府機関を中心に 実施されてきているが，各省庁間の連携がよく取 れているとはいえず，協力の実施機関である各研 究機関, 大学等の協力が日本全体として, バラン スよく進むようにするには，原子力協力に関する 情報を一元的に集めて, その進め方を協議し, 自 らも協力業務を実施できるような原子力途上国協 力専門の調整・実施機関の設置が必要と思われる。

また，これまでの原子力分野における途上国協 力は人材協力に基づくソフトウェアが中心であっ たが，今後は協力の内容が細分化し，具体化して いくとともに機材供与等のハードウェアの協力が 求められることが予想され，そのような際にも， 現在の日本の制度では，途上国のニーズに的確に 底えるには限界があり，この面からも施策の拡充 が望まれる。

原子力先進国として, 日本は発展途上国から大 きな期待をかけられているすのの，これに応えて いくには，体制の問題のみならず，原子力に携わ るもの 1 人 1 人が関心を持つとともに,これに応 えるための努力も必要と思われる。

\section{V. 核不拡散·核軍縮之 原子力の平和利用}

外務省遠藤哲也

現代の科学技術は多かれ少なかれジキル博士と ハイド氏的な二重人格を持っているが，原子力は その点が特に顕著であり, 誕生そのむのからして 原罪を背負っている。すなわち原子力は最む強力 な大量殺りく兵器としての一面と，原子力発電を 中心に人類に無限の恩惠を与える一面とをあわせ 持っている。したがって, 原子力の平和利用の側 面を推進してゆくためには，その裏面であるハイ ド氏の面を極力押さえてゆく，つまり核兵器不拡
散体制をしっかりと確立することが不可欠であ り，換言すれば，核不拡散は原子力平和利用の不 可欠な前提条件といえる。

\section{1. 増える核拡散のおそれ}

ところで，戦後曲がりなりにも維持されてきた 核不拡散条約(NPT)を中心とする核不拡散体制は 目下次のような諸事情により大きな試練に見舞わ れている。

第 1 は，科学技術の進歩につれて，核兵器製 造, 取得技術が運搬手段であるミサイル技術とと あにもはや高嶺の花でなくなってきていることで ある。

第 2 に，ポスト・冷戦期では世界各地で地域紛 
争, 民族紛争, 宗教紛争が頻発する傾向にあり， 6 しそのような紛争当事国が核兵器を保有するよう になると，核兵器の使用されるリスクが高まって くることが䯚念される。冷戦期においてす, 事, 核兵器については米ソはある意味でしっかりと手 を握り合っていたが，ポスト・冷戦期では米口の コントロールは大幅に減退し，不安定な地域の各 国は技術的に容易になった核兵器保有の誘惑にか られやすくなっている。かつては，使われること のない究極の兵器といわれた核兵器がいまや実際 に使われるかもしれなくなっている。

第 3 は，前二者とは趣を異にするが，冷戦の終 結に伴う米ソ(現在はロシア)核軍縮の進展と, ソ 連邦の解体に伴う後遺症から生ずる核拡散のおそ れである。米口両国は戦略兵器削減条約(START I および II)によって戦略核兵器の大幅削隇を約束 しており，2003年までに戦略核弾頭をそれぞれ $3,000 \sim 3,500$ 発に削減することになっている。ま た，戦術核兵器の方は米口それぞれの一方的宣言 であるが，大幅削減を行うことになっている。旧 ソ連邦には戦略核と戦術核あわせて 3 万発に近い 核弾頭があったと推定されるが，それを大幅に削 減するには，非常に長い時間と莫大な経費を必要 とし，その間に, 安全面の問題は言うに及ばず核 拡散のおそれが㮃念される。さらに，旧ソ連邦の 核兵器解体問題を複雑化する要素としてロシアと ウクライナの関係が挙げられる。ソ連邦の解体 後, 核兵器はすべてロシア連邦の単一の管轄下に 置かれることになっており，NPTの下ではロシ アのみが核兵器国として旧ソ連邦の地位を継承 し, 他の諸国は非核兵器国として取り扱われるこ とになっている。ところが，現実に戦略核弾頭は ウクライナ,カザフスタンおよびベラルーシ各国 に依然として配固されており，特にウクライナの 場合ロシアとの関係で，いわゆる「核のカード」を 政治的, 経済的に使っているのか否かはわからな いが，事態は未だすっきりせずゥクライナは戦略 兵器削減条約の批准も NPT への加盟も行ってい ないのが現状である。

ソ連邦解体の後遺症として核拡散上䅣念される 今一つの問題は頭脳流出である。特にロシアに は, 核兵器開発の中枢に関与してきた技術者, 科
学者が 2,000 名以上もいるといわれているが，口 シアの現在の混乱, 変革の過程でこれら技術者, 科 学者の多くは為すべき仕事之経済的な特権を失う に至っている。他方，ロシアの周辺には金に糸目 をつけず彼らの持つ技術, ノウ・ハウを欲しがる国 がないわけではない。ロシア自身も，核兵器専門 家, ミサイル専門家の出国を規制しているとのこ とであるが, 果して所期の効果をあげているのか 否加問題なしとしない。

\section{2. 核拡散防止策}

それでは,このような核拡散のリスクに如何に して対応すべきであろうか。ある国が核兵器の製 造, 保有の誘惑にかられるのには, 安全保障上の 理由, 国家威信上の理由, 経済的な理由など種々 様々の理由が考えられ，核拡散のリスクを払拭す るためには，これらの根本的な理由を取り除かな ければならない。したがって，核不拡散のために は，技術的ないし制度的なアプローチだけでは不 十分であり，国際政治的アプローチが不可欠であ るが，それを前提として本章では，技術的,制度的 アプローチに的を絞ることとしたい。

（1）核拡散防止策の第 1 は，何といっても NPT体制そのあのの強化，確立である。NPT は，1967年の時点までに既に核爆発を行って いた米り英仏中の 5 力国を核兵器国と位置づ け，それ以外の国に対しては非核兵器国とし て核兵器オプションの放棄を求め, その国際 的な証しとしてIAEA の包括的保障措置 ( ルスコープ・セーフガード)の受諾を義務付けて いる。他方, 核兵器国については一般的な核 軍縮の義務を課されているものの, それはど ちらかといえば努力目標的なむので，軍事用 原子力施設に対してはすちろんのこと，民生 用原子力施設等に対しては自発的に申し出る あの(ボランタリー・サプッション)を除いては IAEAの保障措置を受ける必要がなく, NPT は不平等な条約であることは否定のしょうが ない事実である。しかしながら，NPTはこ のような不平等性にあかかわらず，国際政治 の現実をある意味で反映したものであり，ま た1970年の発効以降四分の一世紀の間核不拡 
散国際体制の中核として，核不拡散の国際法 規範として核拡散防止のために大きな役割り を果してきている。

たしかに，現在に至るまでインド,パキス タン,イスラェルといった敷居国 (nuclear threshold countries) はNPTに加入しょうと せず，NPTの正式締約国でありながら秘密 裡に核兵器開発を進めていたイラク，1985年 末以降 NPT に加盟していながら, 保障措置 の適用をめぐってIAEA との間でトラブルの 絶えない北朝鮮など,これまでのNPT の歴 史には紆余曲折があった。しかし，それにも かかわらず，NPTが大きな役割を果してき たといえるのは, 上述のインド,パキスタン, イスラエルも含め 5 核兵器国以外, 世界中い ずれの国も核保有を公然と認めている国は 1 カ国もないこと(南アは過去に核兵器を保有して いたことを公表したが，すでに廃棄している） 核保有への前段階ともいうべき核実験につい ても非核兵器国でこれを実施したのはインド のみであることなどがその一例として挙げら れるのではなかろうか。

いずれにせよ, NPT は近年, 中国および 仏の 2 核兵器国の加入, 敷居国とみられてい た南アフリカの加入をみ, 全楴約国数158力 国という世界で最も普遍的な軍備管理条約と なっている。さらに, 正式な締約国にはなっ ていないが，南アと同様に敷居国とみなされ ていたブラジル,アルゼンチンがIAEA との 間でフルスコープ・セーフガード協定を締結 したことは，NPT加入と実際上ほぼ同じ効 果をむつあのであり大いに歓迎すべきことで ある。

このようにNPT は外延を拡げつつあるの とあわせ, IAEAにいわば業務委託をしてい る保障措置, 查察についても制度の改善·強化 が図られつつある。すなわち, 湾岸戦争の結 果, 明るみに出たイラクの隱密裡の核兵器開 発計画を事前に探知できなかったIAEA は, この苦い経験を教訓にして, 查察制度の補強 のためにこれまで余り使われていなかった特 別查察制度の活性化に取り組んだのであり，
昨今問題になっている北朝鮮の $2 つ の$ 施設に 対する特別查察の要求は, この制度が活性化 された後の初めての事例である。

このような状況の下に, NPT は発効して から25年後の1995年に協定の延長会議を迎え る。すでに協定延長問題をめぐっていろいろ な動きが出始めているが, 日本は先進国首脳 会議 (G 7)の他の諸国とともに無期限延長支 持の立場を明らかにしている。しかしなが ら, NPT の不平等性, なかんずく核兵器国の 核軍縮義務，より具体的に言えば，核実験禁 止問題に対する一部非同盟諸国の反発には根 深いすのがあり，延長会議を成功裡に乗り 切って，NPTを堅固不動なすのにするため にはようやく軌道に乗りかかった全面核実験 禁止条約の検討の促進と, 米口間の核軍縮の みならず，中級核兵器国による例えシンボ リックなむのなりとむ核軍縮への具体的な対 応などが望まれるところである。

(2) NPT が核不拡散体制の中枢を占めるもの であることはこれまでも強調してきたが, NPT は万能薬ではない。NPTに加盟しょう としない敷居国す少なくないし，NPT加盟 国であってあ核疑惑のつきまとっている国す あり，核不拡散体制を一層しっかりしたもの にするためにはNPTを側面から補強する措 置が必要である。

1974年 5 月のインドの核実験を契機とし て, 原子力先進国が集まり，いわゆる「ロン ドン・ガイドライン」として実施するに至った ${ }^{235} \mathrm{U},{ }^{239} \mathrm{Pu}$ な゙゙の特殊核分裂性物質, 原子炉, その付属品および技術などに対する非核兵器 国への輸出規制措置がこれであり(ロンドン・ ガイドライン.パートI），昨今は技術の汎用性 が高まって来て，直接原子力に関連する原子 力専用品目の輸出規制だけでは核不拡散対策 上不十分であるとして，原子力沉用品す規制 対象とした輸出規制措置(ロンドン・ガイドライ ン・パートII)すここれに該当する。

このロンドン・ガイドラインに参加してい るのは現在 28 カ国であるが, 今やアルゼンチ ン,ブラジル, 中国, インド,暲国といった新興 
の供給可能国が出現しておりこれら諸国も 適宜参加してもらう必要性が高まっている。

（3）以上は，いわゆる従来型の核拡散のリスク に対する対応策であったが，ソ連邦解体の後 遺症に由来するリスクは非伝統的な新しい夕 イプのリスクであり，これに対しては特別の 対応策を必要とする。

まず, 核兵器の解体とその後始末の問題である が，核物質の流れとして，現場における核弾頭部 分の取り外し， ロシア内の解体場所への搬送, 解 体，解体によって出て来た Pu 掞よび高濃縮 U の 一時詝蔵，そして最終処分 (売却, 燃烧, 永久眝蔵な ど)が想定されるが, いずれにしてもこのプロセ スに非常に長い時間之莫大な費用を必要とするこ とは前に述べた通りである。この作業はロシアが 第一義的に責任を負うべきものであるが，現在お よび近い将来のロシアの経済状況からしてロシア のみでこれを負担することは到底無理な話であ り，国際的な協力が必要である。米国はすでに多 岐にわたる分野での協力を開始しており，英仏独 伊などNATO(北大西洋条約機構)諸国す前向きの 姿勢をとっている。我が国としてもこのために約 1億ドルの予算を計上し，具体的な協力内容とし て, 例えば解体後に出て来る Puや高濃縮 U の貯 蔵施設の建設への協力およびこれら核物質の平和 利用研究, 有害物質とされるミサイルの液体燃料
の処理, 核兵器関連施設の環境污染への対応など 何が適当かを今後ロシア側とつめてゆくことに なっている。

第 2 の頭脳流出防止については，その対応策の 一つとして, ロシア, 米国, EC, 日本等の協力によ り拋出額 8,000 万ドルくらいの予算規模でモスク ワに国際科学技術センターを設立することになっ ており，近く発足の予定である。

\section{おわりに}

我が国においては，筆者の見るところ原子力の 安全には人一倍の関心が払われており，それはそ れで大いに結構なことであるが，核拡散問題につ いてはそれほどの関心は持たれていないようであ る。これはおそらく，唯一の被爆国, 非核三原則 を堅持する国として自分がそうであるから他人す そうであろうと，核の不拡散をあまりにあ当然視 しているからではなかろうか。しかしながら，他 が日本を見る目はそう甘いものではないことを十 分認識しておくべきであろう。核の拡散を防止す ること,そしてさらに進んで核軍縮を推進するこ 之は国際の平和と安定のために絶対に必要である し，また，それが故に核搪散の防止および核軍縮 は原子力平和推進のためにも不可欠であることを 最後に重ねて強調しておきたい。

（本稿は，筆者の個人的見解に基づくあのである ことをお断りしておきたい。）

\section{VI. まとめ}

IAEA 町末男

リオの環境サミットであ大きな課題となった $\mathrm{CO}_{2}$ 抑制問題への対応は原子力抜きには考えられ ない。エネルギー消費の $90 \%$ は依然として $\mathrm{CO}_{2}$ を 発生する化石燃料によって賄われており，原子力 はまだわずか $5 \%$ を占めるに過ぎない。太陽エネ ルギー等の再生可能エネルギーの利用の実現には 経済性から考えてかなりの年月を必要とする。

石田氏は今後のエネルギー需要の大幅な増加 （1990年から2010年の間に電力需要は 2 倍になると予測
されている)を賄うため, 持続的な経済発展のため に原子力発電の重要性が見直されつつある之指摘 している。経済発展の勢いの強いアジアで原子力 発電が進展する一方， ヨーロッパ, 米国での停帯 は続いている。IAEA は原子力発電の今後2015年 までの伸びを，欧米での停滞が続くと仮定して 13\%増, 欧米での復調, アジア, 東欧での計画が順 調に進めば70\%と予测している。

新政権下の米国では，原子力研究開発予算は核 融合, 廃裹物処理以外は削られ,これから寿命の 来る多くの原発を新原発に置き換えることすらす 見通しがつかないという。新政権はPuの民生利 用に消極的だが， 日本, 西欧諸国の間にすでに存 
在する $\mathrm{Pu}$ 利用計画についてのコミットは守ると している。

日本の Pu 利用政策は国際的な関心事となって いる。誤解を招かないような十分な説明と PRが 必要である。Puの透明性を增すために国際Pu管 理の方策が日本の主導で議論されていることは非 常に好ましいことである。

旧ソ連, 東欧では様々な問題が発生している。 原発の安全確保には緊急な対策が必要であるとの IAEA の専門家の強い勧告に基づき, G 7 サミッ トで支援が決定した。G24の東欧支援の一環とし て, 原子力安全支援調整センターが設立され活動 が始まった。IAEAを技術アドバイザーとし，資 金は多国間および 2 国間の支援による。日本の貢 献は大きい。早急な実効を期待する。

旧ソ連の核兵器関連の科学技術者の頭脳流出を 防止し，平和目的に活用するため，日，米，口，EC で設立調印をした後，1年以上もロシアで批准が できず発足が遅れていた国際科学技術センターが 批准なしで発足できるという議定書に 4 極が合意 し, 活動開始の見通しがついたのは1993年末の朗 報である。

チェルノプイリ事故の放射線影響については, IAEA の報告書が1991年に出て, 白血病, 甲状腺 疾患などに際立った異常はないとされている。今 後WHOが国際研究機関を設置し, 上り詳細な調 查, 対策, 不安感の解消などの活動を行うことを決 めた。

IAEA の Auspice (賛助)の下で進められている ITERでは，各極のサイトが重要なマイルストー ンとなる工学設計活動を開始した。国際共同作業 によるその成果が楽しみである。一方, JT-60で はプラズマ電流の1.8倍堌に成功, TFTR は D-T 燃焼に成功するなど，画期的な成果が得られ，核 融合は勢いづいている。IAEA は核融合を将来の 重要な原子力エネルギーと位置付けて開発途上国 にも協力しつつプロジェクトを推進している。 ITERについても事務局を有するほか，核データ の整備・提供, 共通支出のためのジョイントファン ドの設置など, 予算の許す限りの協力を提供して いる。

日本の長期エネルギーの確保に必要な Pu利用
は各国が注目している。「あんじゅ」をCOE(Center of Excellence) として国際協力之国際貢献に役立て るという提案が日本からされているのは大変好ま しいことである。鈴木氏は, 高速炉の将来の課題 は経済性之安全性の確保であると指摘している。

日本の開発途上国協力は, 原子力の分野でむ積 極的に進めるという原子力委員会決定が出てから 10年近くになり，放射線・RI利用を中心に，人材 交流, 共同研究などが拡大定着して, 途上国から 感謝されると共に，日本の研究者の国際化にも役 立っている。今後はアジア地域から，日本の支援 に期待を寄せる他の地域への拡大が課題となる う。

原子力はジギルとハイド的側面を持つと，遠藤 氏は指摘する。核拡散防止の重要性, 問題点は第 IV 章に明解に述べられている。日本はすでに NPT の無期限延長の支持を表明している。日本 の原子力の発展のために $\mathrm{Pu}$ な゙核物質および原 子力施設の管理を出来る限り国際的に透明化して おくことが大事である。IAEA は核査察の強化, 効率向上, 合理化に取り組んでおり成果が期待さ れる。北朝鮮の査察は政治問題化しており，早期 解決が強く望まれる。1994年になって米朝交涉が 一歩前進, 北朝鮮はIAEA の通常査察を受け入れ る姿勢を示している。

旧ソ連の解体に伴って幾つもの問題が生じてい る。例えば，ウクライナには核弾頭が依然として 配圈されているが, リスボンプロトコールに反 し，ウクライナはまだNPTに加盟していない。 この点はIAEA の1993年12月理事会です各国が強 く指摘したところである。幸い1994年 1 月14日， ウクライナはロシア, 米国に対し，NPT に加盟 し, 国内に配備されている核兵器の解体を進める ことに合意する文書に署名した。

以上，原子力の将来は技術面のみならず，国際 的・政治的な情勢に深く関わっていることが，現 実にこれらの問題に取り組んでおられる方々の報 告によって具体的に示され，大変に興味深い「特 集」となりました。お仙しい時間を割いて下さっ た執筆者の方々に感謝いたします。

（1994年 1 月17日稿，ウィーン在住） 